\title{
طبيعة عقود البوت وآثارها القانونية
}

* إبراهيم هجاهدى

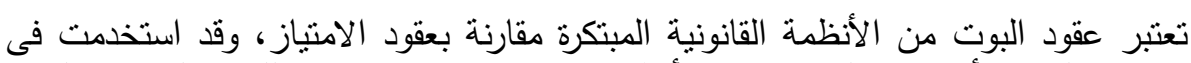

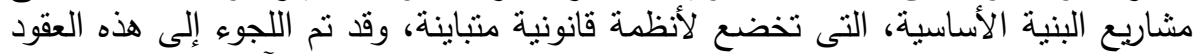

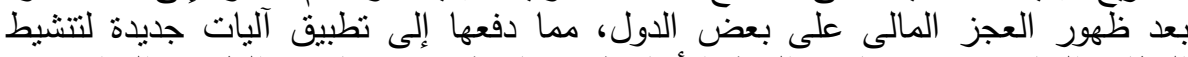

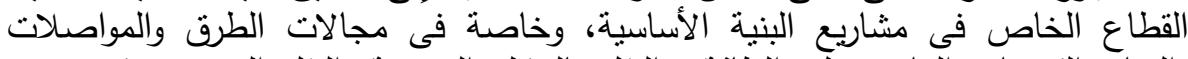

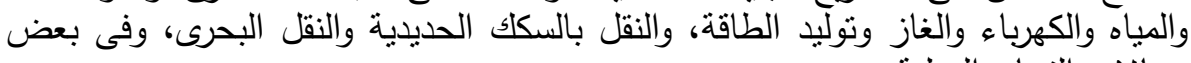

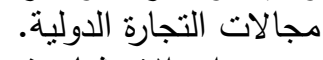

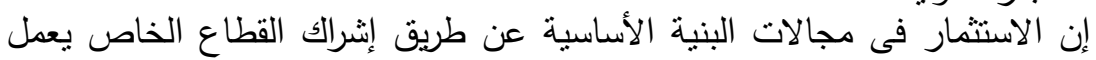

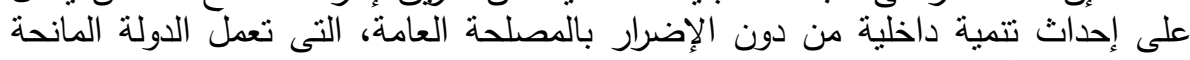
ل ل لهذه العقود على حمايتها.

\section{مقدهة}

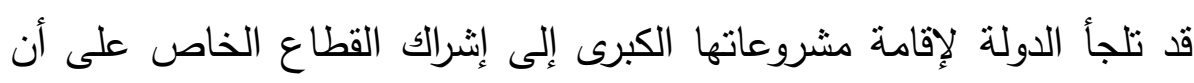

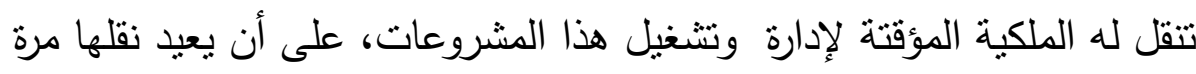

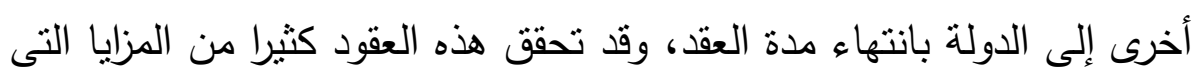

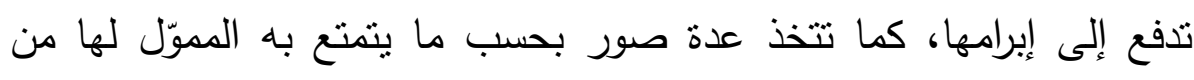

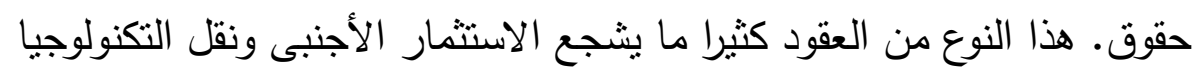

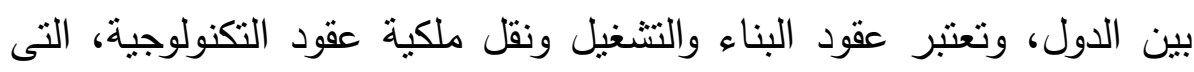

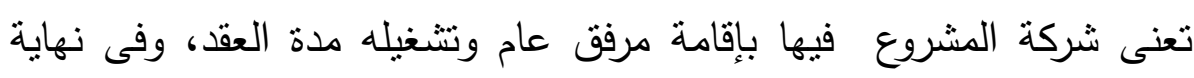

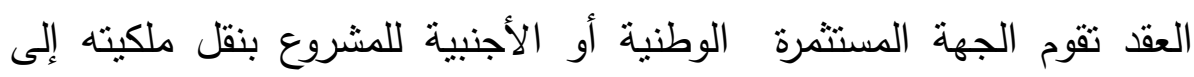

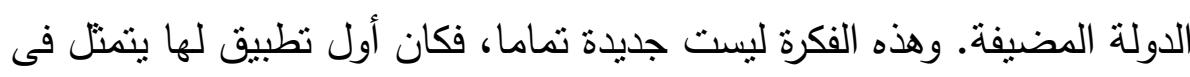

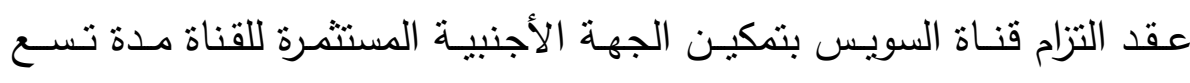
* أستاذ محاضر (أ)، كلية الحقوق والعلوم السياسية، جامعة البليدةr.

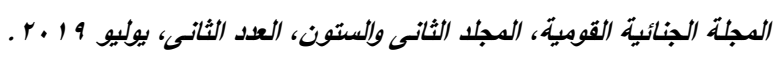


وتسعين عاما، وفى نهاية هذه المدة تتم إعادة نقل ملكية المشروع للدولة

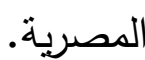

إذا كانت لعقود البوت منافع اقتصادية، فلها مخاطرها السياسية، التى

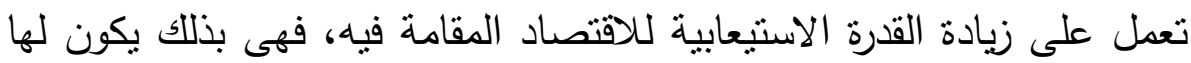
قدرة كبيرة على جذب الاستثمارات المحلية والأجنبية، بهدف تحقيق أمرين،

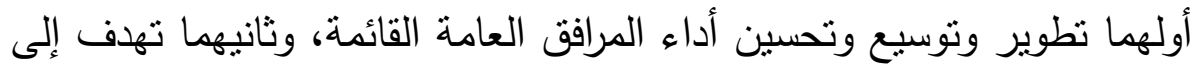
إنثاء مرافق جديدة بتمويل من القطاع الخاص، فهى فى هذا الدجال تعمل على تحسين ظروف التتمية عمل الاقتصاد فى الدولة المستثمرة، وذلك من في هن خلال: تخفيف العبء عن الموارد الحكومية المحدودة، والتتجيع على إقامة مشروعات ومرافق عامة جديدة، نوفير البيئة المناسبة للتتمية الاقتصادية، واستفادة الحكومة من خبرة القطاع الخاص فى تقديم الخدمة العامة. على أن هذه الامتيازات قد تشوبها كثير من العيوب التى تشكل عبئا

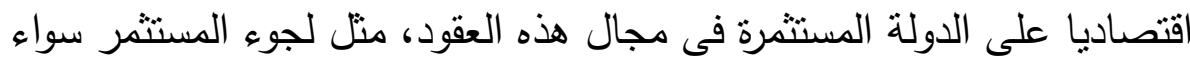

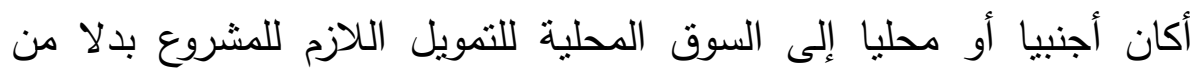

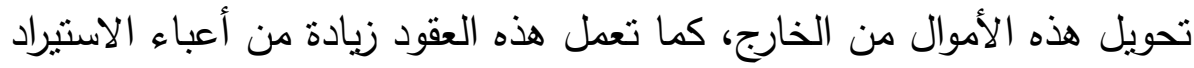

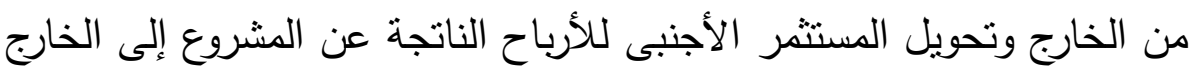

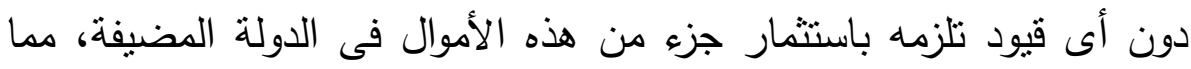

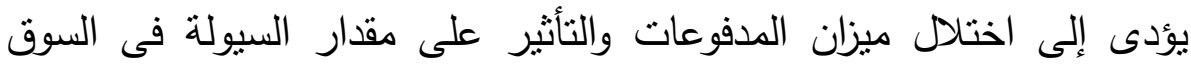

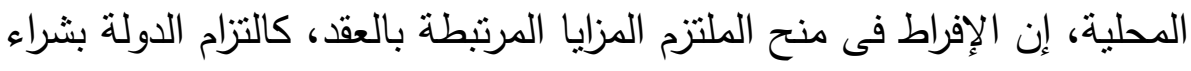

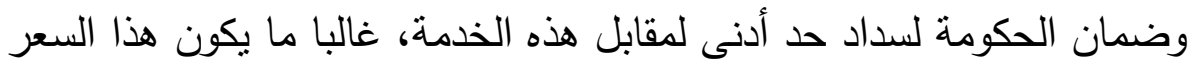

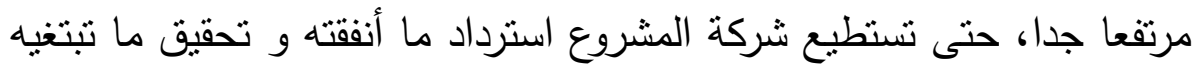
من ربح، ويكون هذا السعر بالعملة الصعبة التى تقوم شركة المشروع بتحويله 
للخارج إلى حساباته من دون فرض أية رقابة من البنوك المركزية فى الدولة المضيفة على هذه الأموال المحولة. كما تقوم شركة المشروع باحتكار السوق دانه

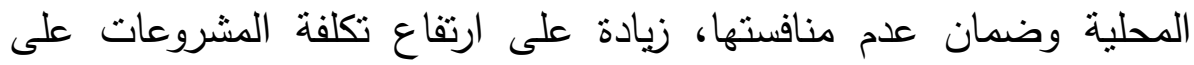
المدى الطويل خاصة إذا تعلق الأمر بشراء الدولة للمنتج.

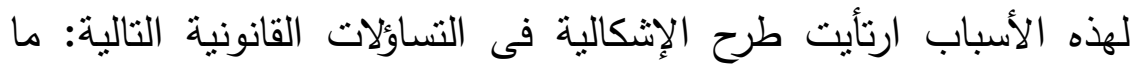

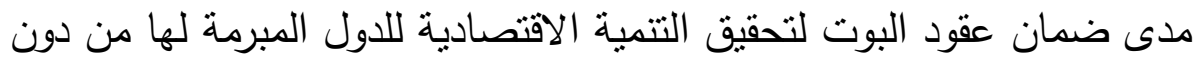

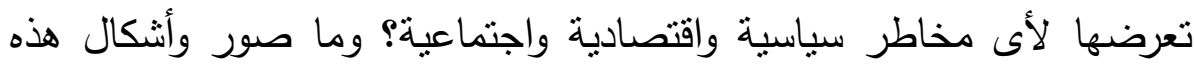
العقود؟ وما الإطار القانونى المنظم لها؟ وما طبيعة الالتزامات والحقوق

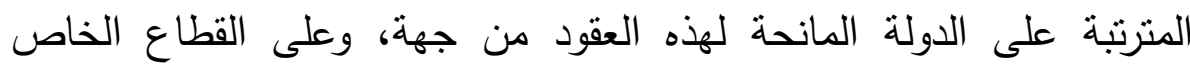

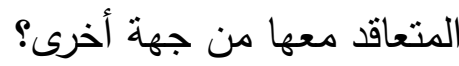

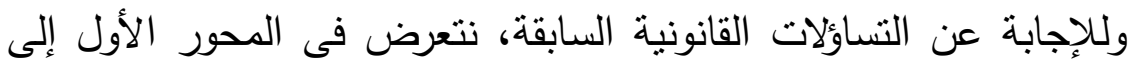
بيان ماهية عقود البوت، وفى المحور الثانى نتطرق إلى إطارها القانونى، وفى القى المحور الثالث نبيّن الحقوق والالتزامات المترتبة عليها.

\section{الحور الأول: هاهية عقود البوت}

تعتبر عقود البوت أحد أساليب التتمية التى نسمح بمشاركة القطاع الخاص

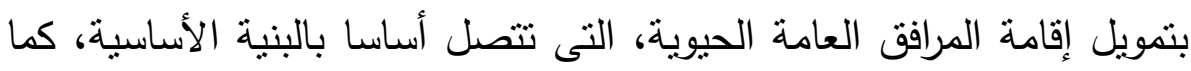

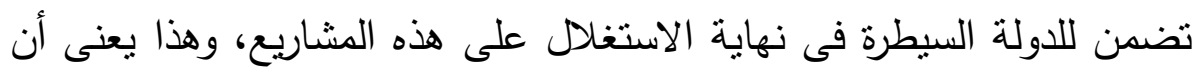

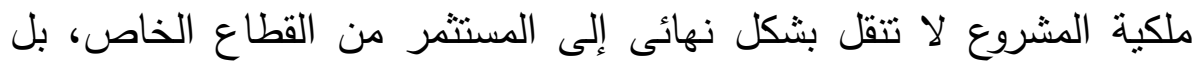
تظل ملكيتها للدولة المضيفة طوال الفترة التعاقدية. تسهم عقود البوت بدور فعال فى تحقيق التتمية الاقتصادية للدولة، عن طريق إقامة مشروعات البنية الأساسية من أجل تغطية الأعباء النقيلة الناتجة 
عن إنشاء هذه المشاريع، كما تعتبر هذه العقود وسيلة لنقل التكنولوجيا الحديثة

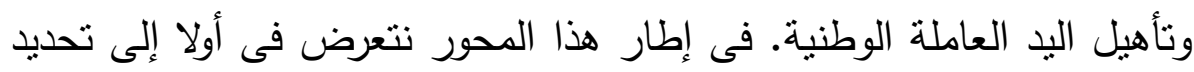
مفهوم عقود البوت، وثنانيا خصائصها، وثالثا صورها وأنثكالها.

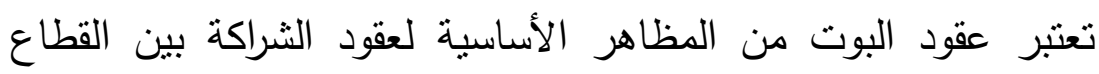

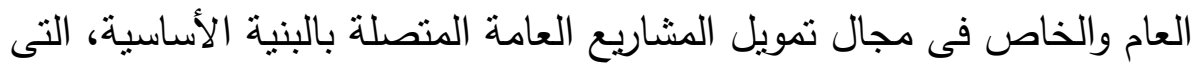

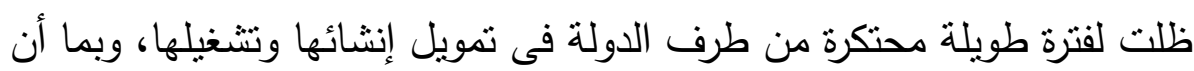

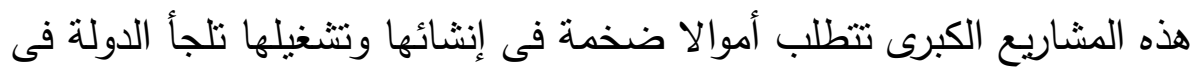

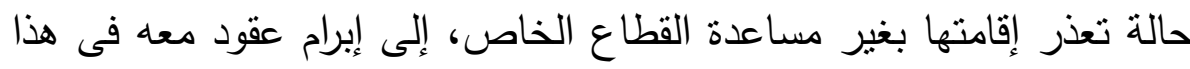
المجال، وذلك بنقل ملكيتها لله بصفة مؤقتة، بشرط أن يقوم هذا الأخير بإعادة إنهاة

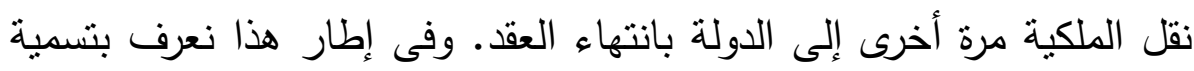
هذه العقود، ثم تعريفها الفقهى، ثم تعريفها القانونى لها.

\section{ا - تعريف تسمية عقود البوت}

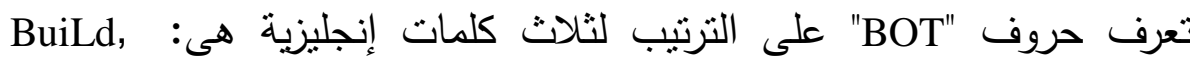
Operate, Transfer

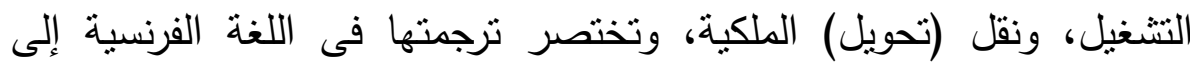
Construire, Exploiter, : (CET) Transférer

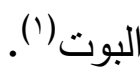
انتقال الملكية فى عقود البوت لا يعنى انتقالها نهائيا من الدولة إلى الطرف

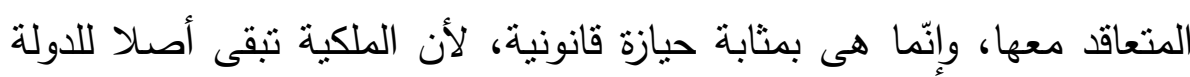

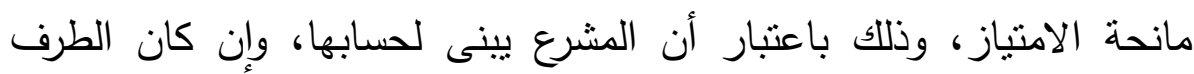


المتعاقد مع الدولة وما تم نقله إليه من ملكية مؤقتة، فهو ملزم عند انتهاء مدة

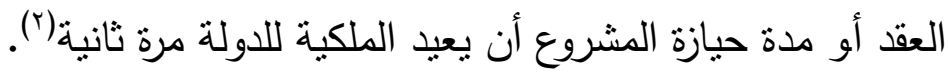

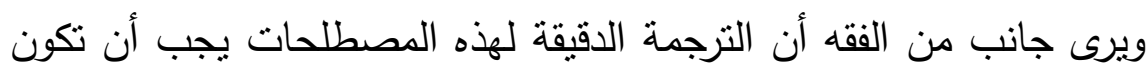

كالآتى: التنييد، الاستخلال والتنليم، و وحتنه فى ذلك كالآتى (r): أ- إن مصطلح التشييد أكثر دقة ودلالة فى الواقع من مصطلح البناء، التهاء

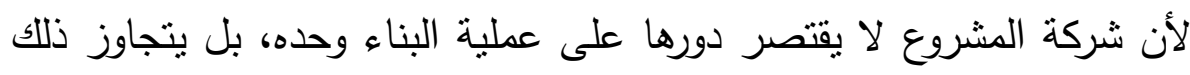

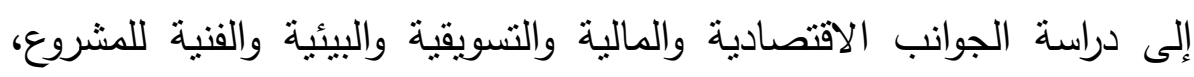

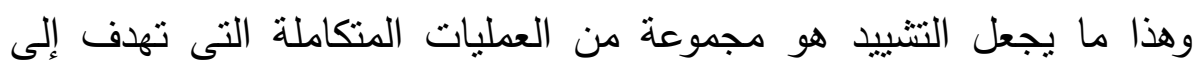
التجسيد الواقعى للمشروع، وما عملية البناء إلا جزءا من تلك العطليات.

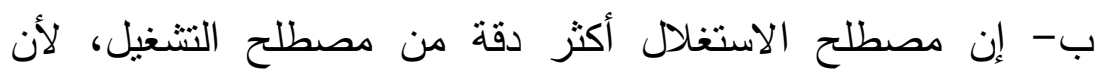

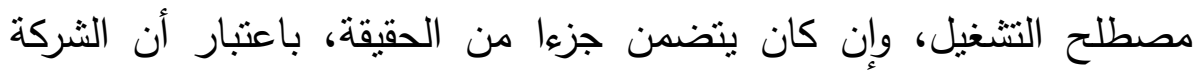

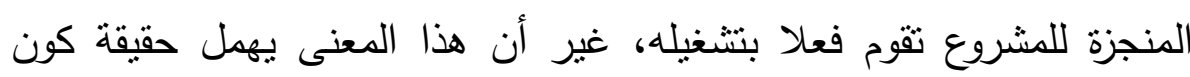

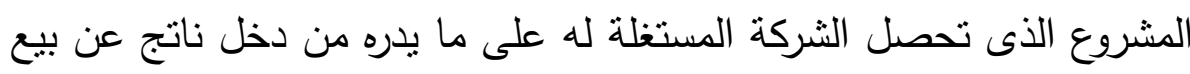

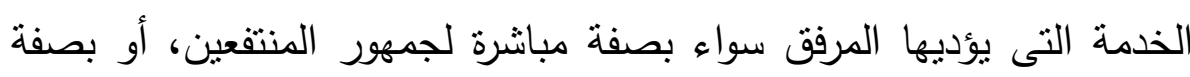

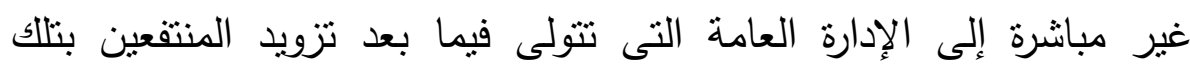

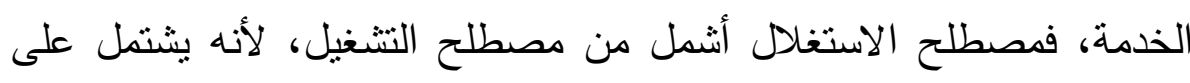

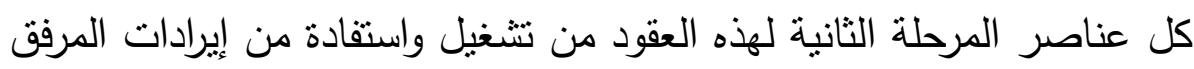
موضوع التعاقد. ج- إن مصطلح نقل الملكية يعنى أن شركة المشروع تمنلاك المرفق

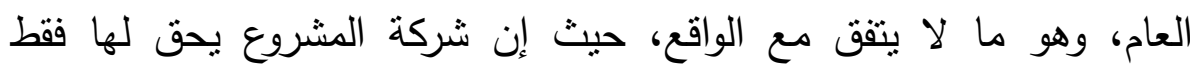

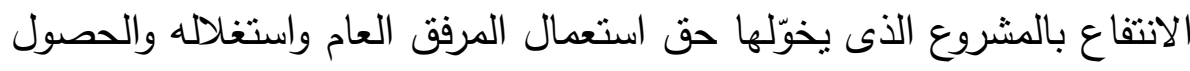


على مقابل الخدمة المقدمة، فملكية المرفق العام منعقدة للجهة الإدارية صاحبة الملكية الأصلية، وبالتالى فلا يمكن لثركة المشروع أن تتقل ملكية ما لا تملك.

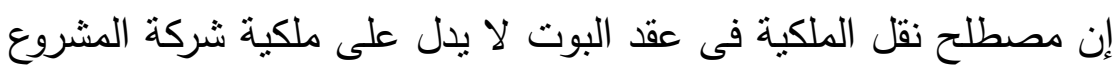

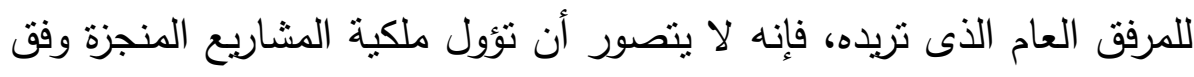

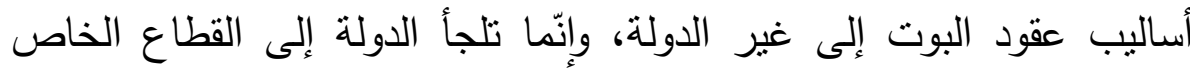

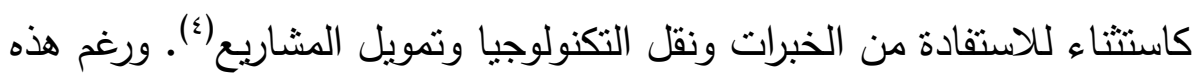

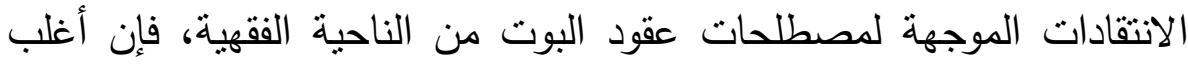

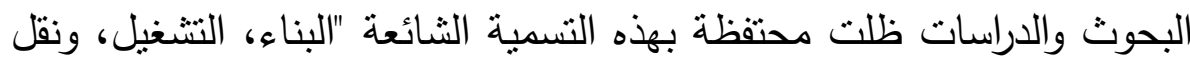

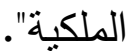

\section{r- التعريف الفقهى لعقود البوت}

تعرف عقود البوت على أنها" تلك المشروعات العامة التى يقوم القطاع الخاص

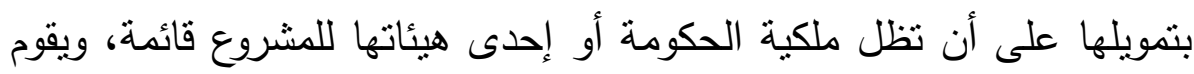
القطاع الخاص بتصميم وبناء وإدارة المشروع خلال فترة محددة، يرنبط فيها

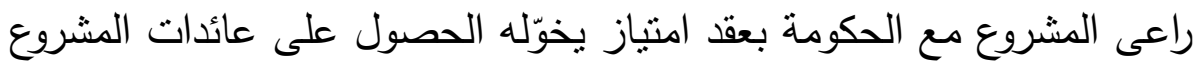

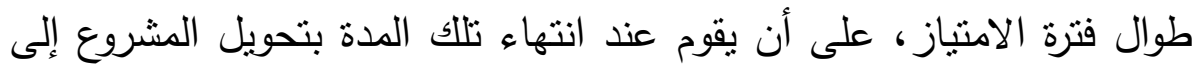

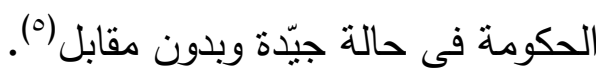
وهذا المفهوم ما أكده الدكتور جابر جاد نصار فى تعريف عقد البناء

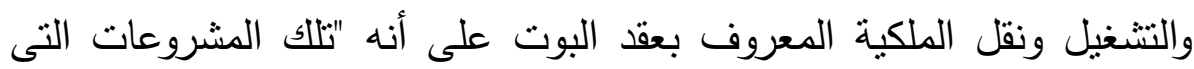

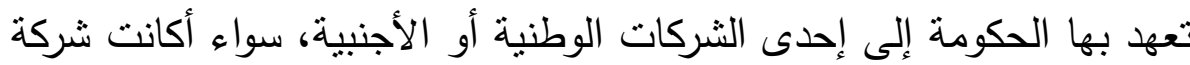

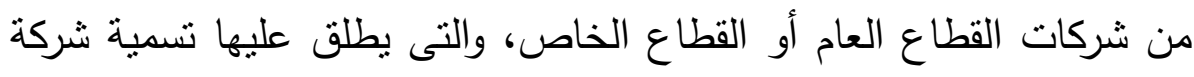


المشروع، وذللك لإنشاء مرفق عام وتتغيله لحسابها مدة من الزمن، ثم نقل

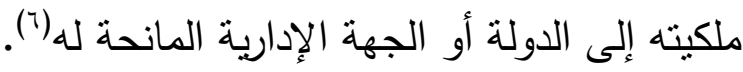
ويذهب اتجاه فقهى إلى أن عقد البوت عبارة عن "تنظيم تقوم الدولة الدانه

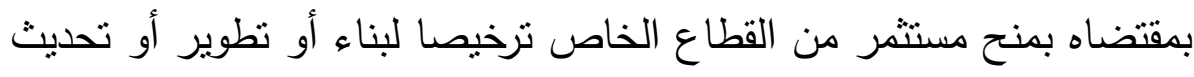

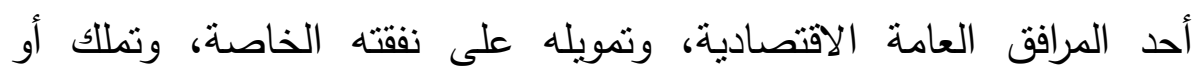
استئجار أصول هذا المرفق، وتشغيله بنفسه أو عن طريق الغير ، ويكون عائد الأدئ تتشغيل المشروع فى معظمه خالصا له طول مدة الترخيص، ويلتزم المستثر

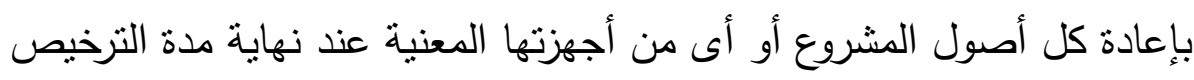

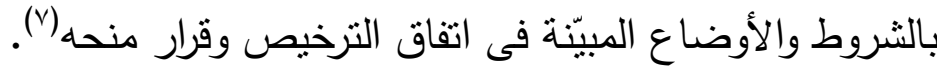
وعرفه آخرون على أنه "ثكل من أنشكال تمويل المشاريع تمنح بمقتضاه

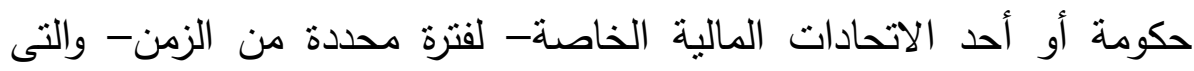

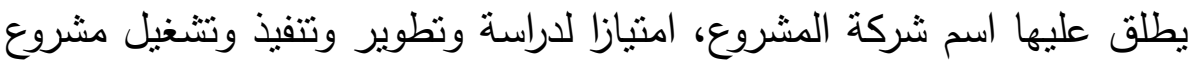

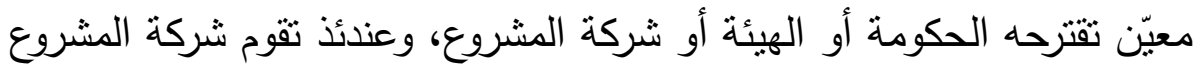

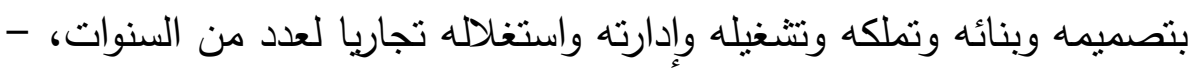

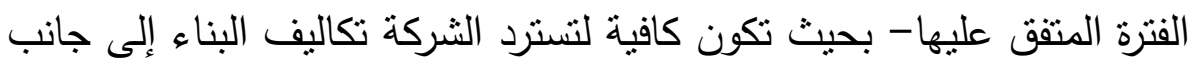

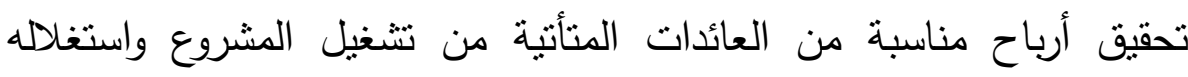

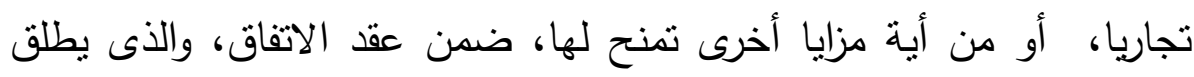

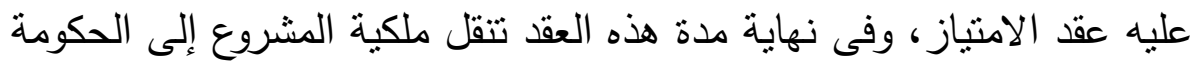

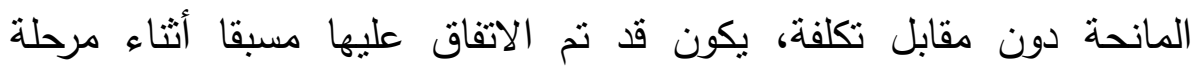

$$
\text { التفاوض على المشروع"((). }
$$

وقيل إن عقد البوت هو "عملية منح الحكومة لمن برغب فى الاستثمار

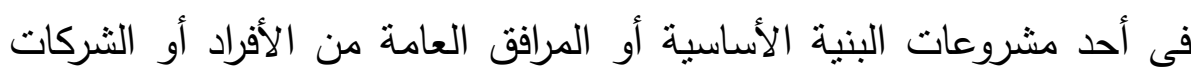


الخاصة فرصة إقامة المشروعات على الأرض التى تحددها الدولة للمستثر وتحمله أعباء شراء، وتزويد المشروع بالآلات والمعدات والتكنولوجية المنقدمة الأنية

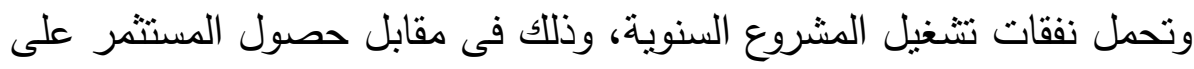
إيراد تثغيل لمشروع، خلال فترة تحددها الحكومة، والتى تعرف بفترة الامتياز ،

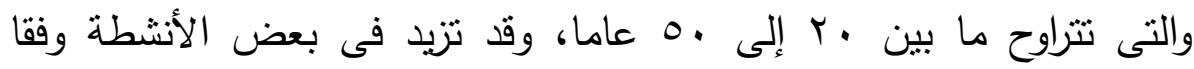
لتقديرات واعنبارات المصلحة القومية، وبعد انتهاء الفترة المحددة فى العقد، يتم تحويل المشروع أو المرفق إلى الحكومة التى يحق لها التصرف فى مصبره وفقات التهاء

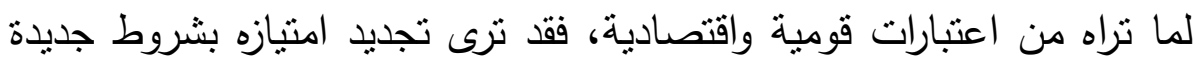
تختلف عن تلاك الواردة من قبل، وقد ترى منح امتياز تثغيله إلى مستثمر آخر

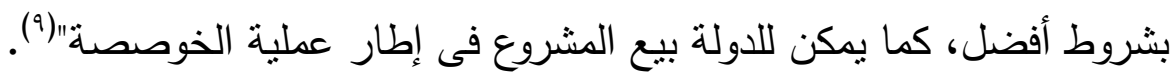

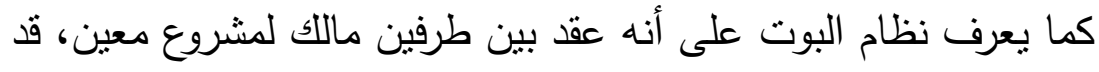

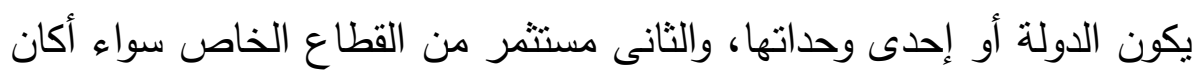

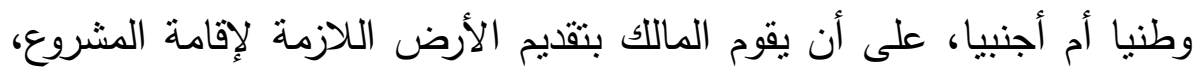

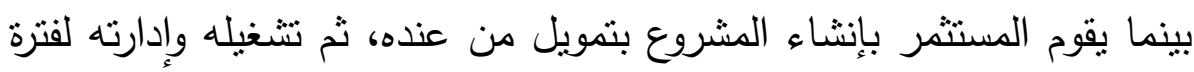
من الزمن، يتم الاتفاق عليها، يستغل فيها المستثر المشروع ليستعيد ما أنفقه بئه

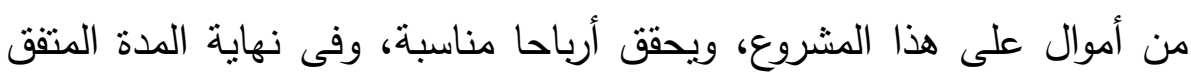

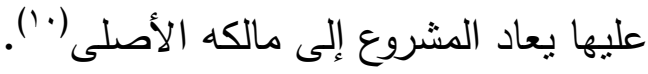

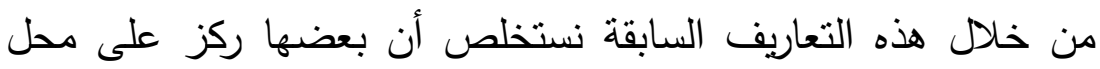

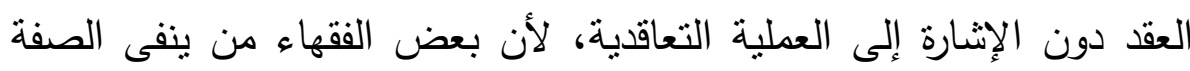

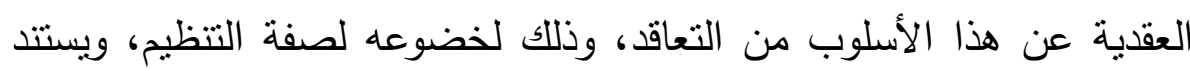

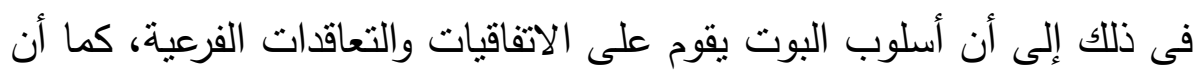
بعض هذه التعاريف قصدت التزامات شركة المشروع على عمليات الإنثاء فقط التط 
دون أن تمتد إلى دور الصيانة والتجديد والتحديث، وهو ما ينتافى مع حقيقة هذه العقود.

كما أن بعض التعريفات الأخرى جاءت مركزة على الجانب الاقتصادى

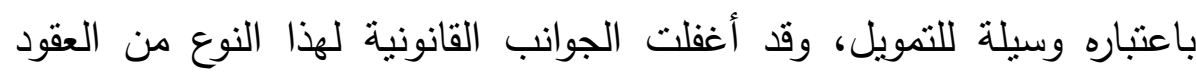

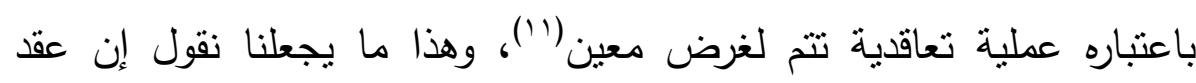

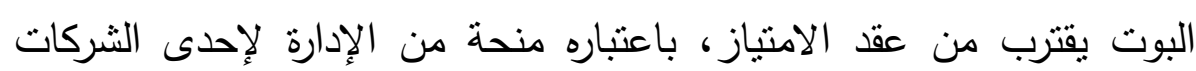

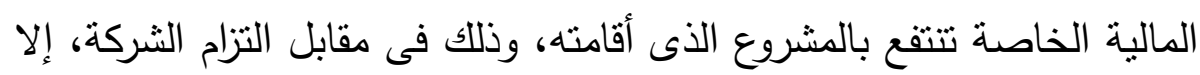

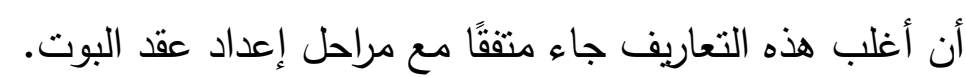

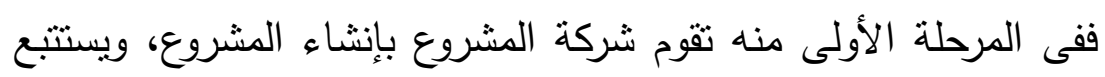
ذللك القيام بتدبير التمويل اللازم، وضبط التجهيزات والآلات الضرورية المنطلبة لتصنية

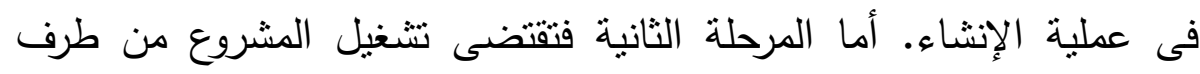
الثركة الراعية للمشروع، وذلك بهدف تحقيق عائد مالى يغطى تكاليف إنجاز المشروع، ويدر على المستثر عوائد فى شكل رسوم ينقاضاها من جمهور المنتفعين، وفى نهاية الددة المتفق عليها تتنقل حيازة المرفق إلى الدولة أو الد

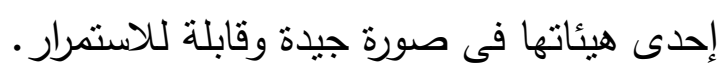

\section{r- التعريف القانونى}

جاء فى تقرير لجنة الأمم المتحدة للقانون الدولى (CNUDCI) أن مشاريع

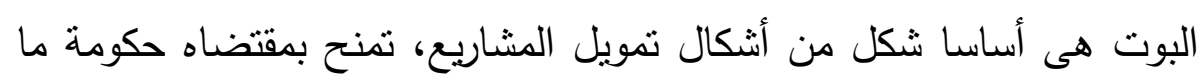

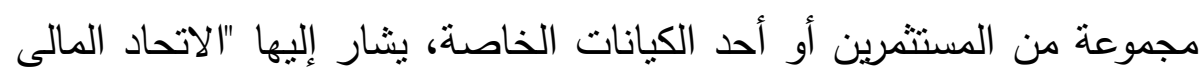

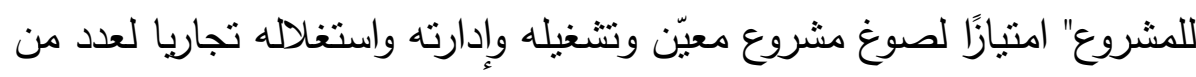
السنين، تكون كافية لاسترداد تكاليف البناء، إلى جانب تحقيق وأرباح مناسبة ولثين 
من العائدات الكتأتية من تشغيل المشروع، وفى نهاية الددة تنقل ملكية المشروع إلى الحكومة، دون أية تكلفة أو مقابل تكلفة مناسبة، يكون قد تم الاتفاق عليها

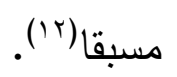

وقد عرفت منظمة الأمم التنحدة للتنمية الصناعية UNIDO عقد البوت

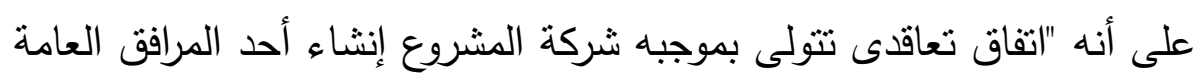
الأساسية فى الدولة، بما فى ذلك تلك عملية التصميم والتمويل والقيام بأعمال

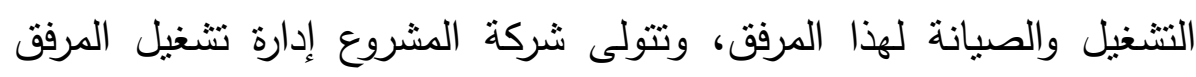

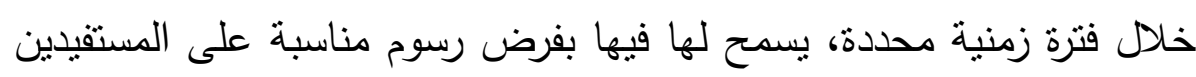

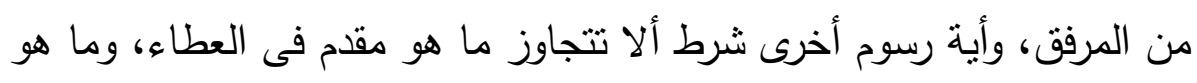

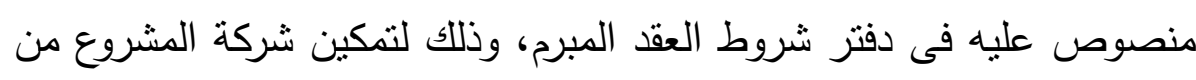

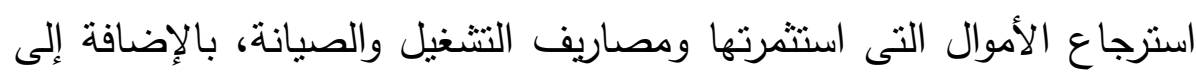

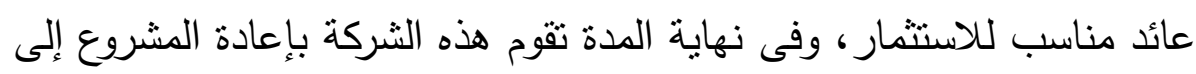

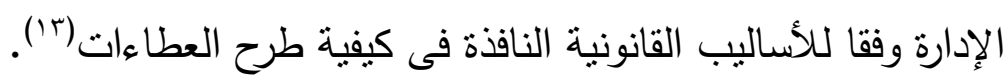

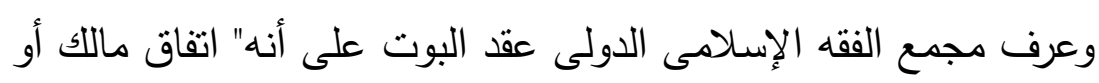

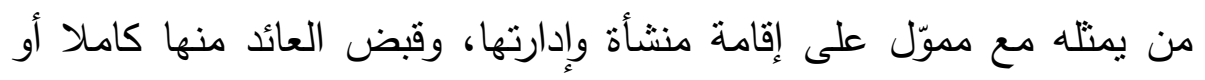

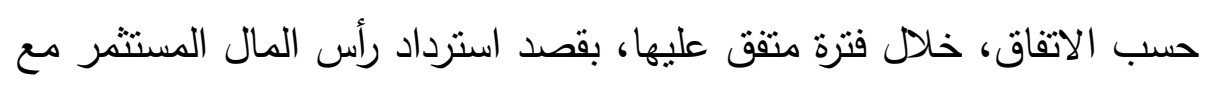

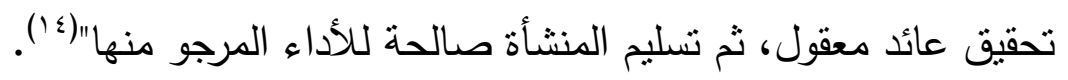

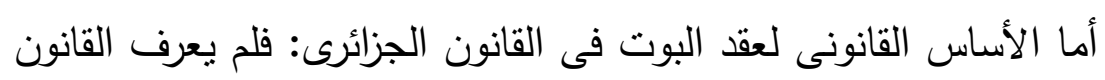

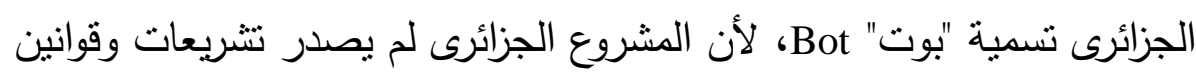

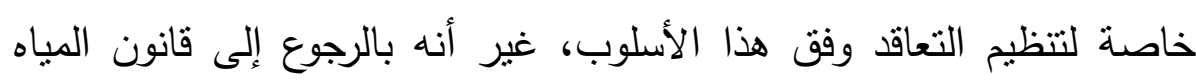

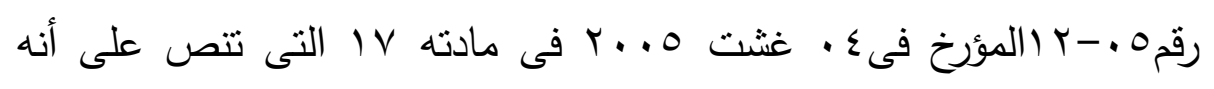
"تخضع كذلك للأملاك العمومية الاصطناعية للمياه، المنشآت والهياكل التى كانى 
تعتبر ملكا يرجع للدولة بدون مقابل بعد نفاذ عقد الامتياز أو التفويض للإنجاز

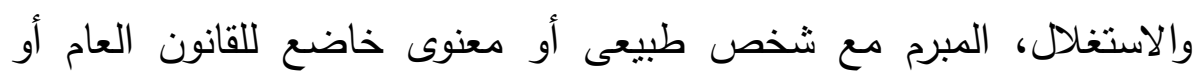

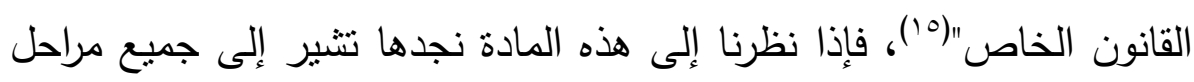

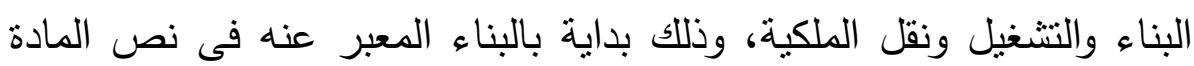
بالإنجاز ، ثم الاستغلاه وهو ما يقابل مصطلح التشغيل فى عقد البوت (Bot)

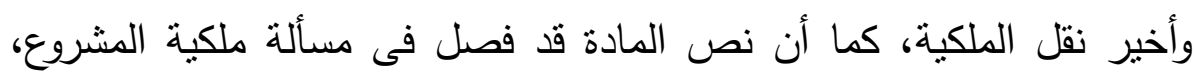

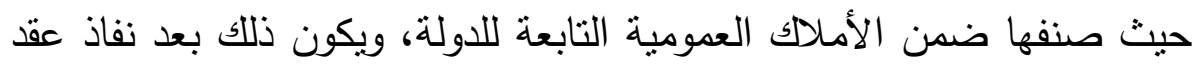
الامتياز أو التفويض، حيث تسترجع هذه المنشآت إلى أملاك الدولة.

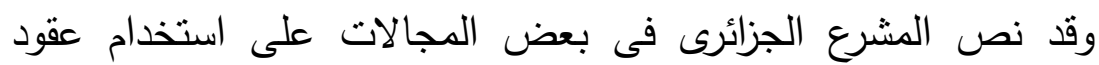

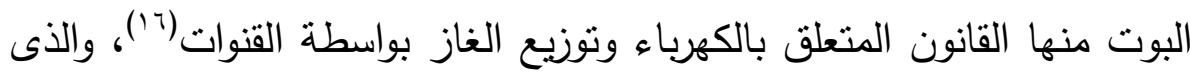

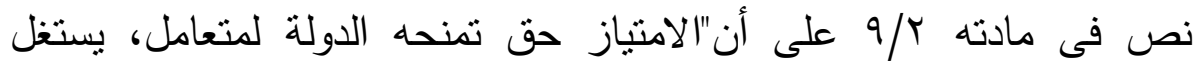

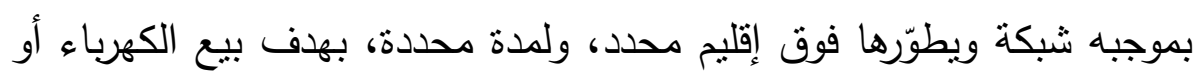

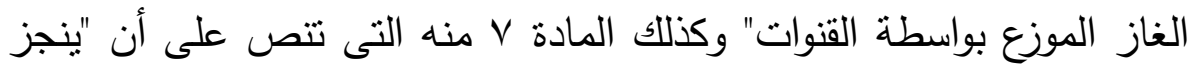

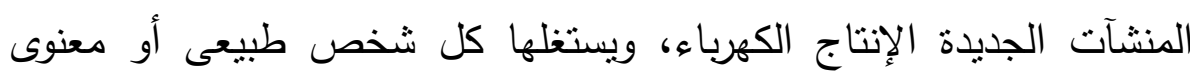
خاضع للقانون الخاص أو العام ، حائز رخصة استغلال".

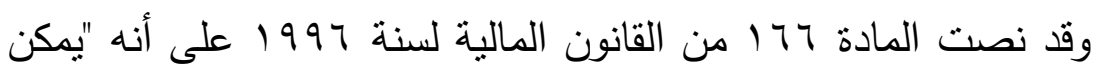

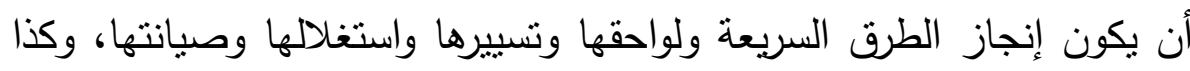

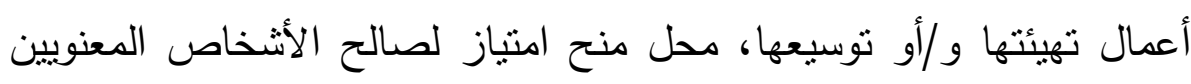

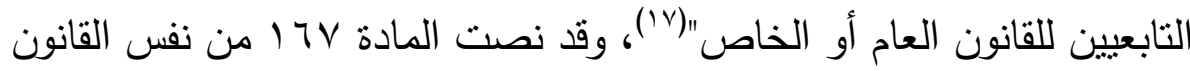

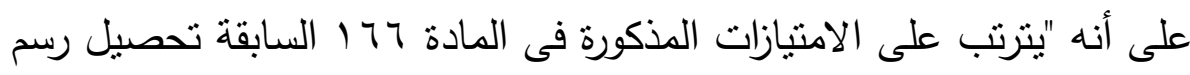

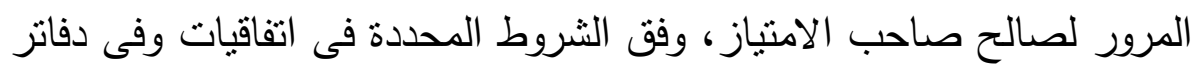


الثروط المرتبطة بها"، وبذلك تكتمل جميع العناصر المنطلبة فى عقد البناء

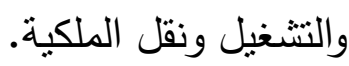

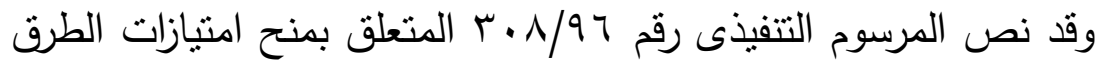
السريعة فى مادته الأولى على أن "يخضع إنجاز الطرق السريعة وملحقاتها

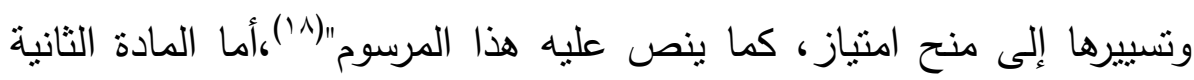

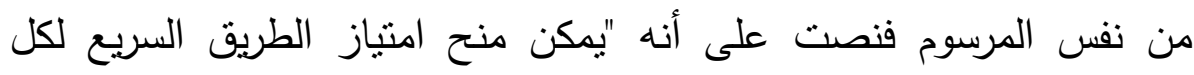

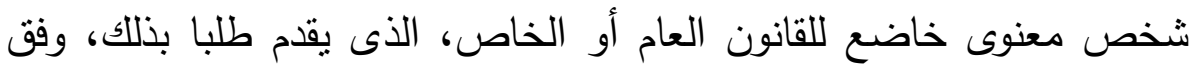
شروط وتعليمات دفتر الأعباء النموذجى الملحق بهذا المرسوم". وتتص المادة الأولى من الاتفاقية النموذجية الخاصة بمنح التنياز

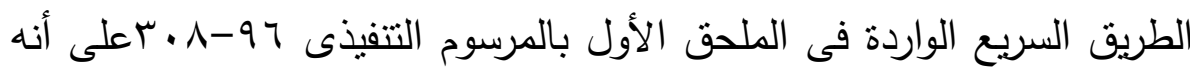

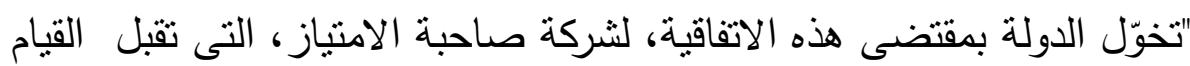

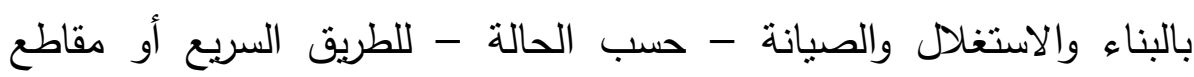

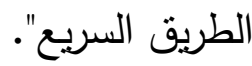

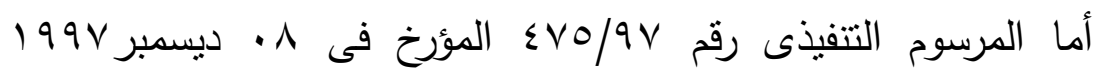

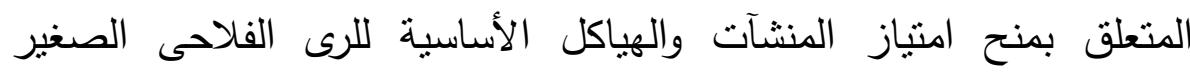

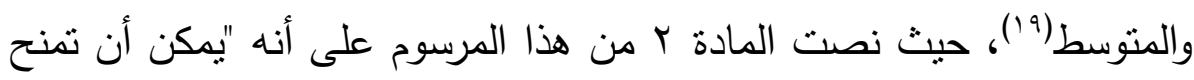

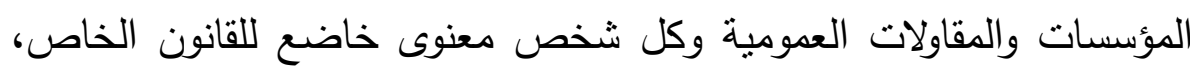
وتتوفر فيه المؤهلات المهنية امتياز تسيير واستغلال وصيانة المنشآت والهياكل الأساسية للرى الفلاحى الصغير والمتوسط".

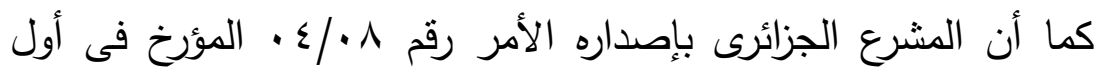

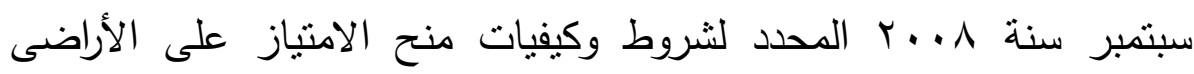

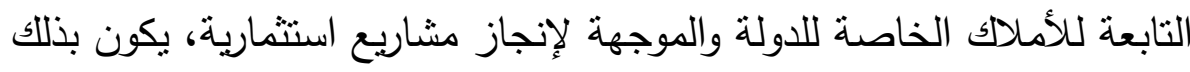


قد فتح المجال للتعاقد بأسلوب البوت، باعتبار المشاريع المنشأة نطبيقا لهذا

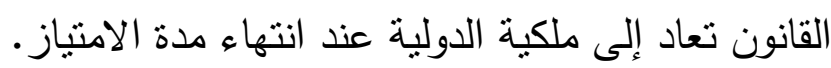

\section{ثانيا: خصائص عقود البوت}

ترتبط عقود البوت بصفة عامة بمشاريع البنية الأساسية الخاضعة لرقابة

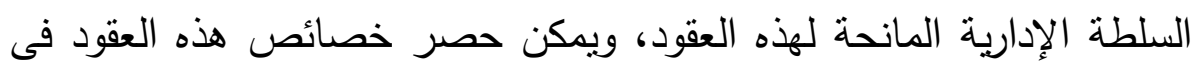

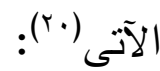

1- ارتباط عقود البوت بمشاريع البنية الأساسية: تقوم عقود البوت

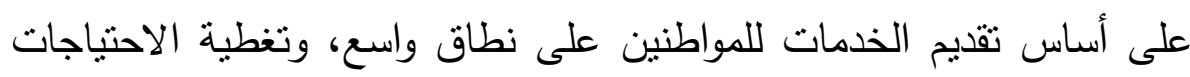

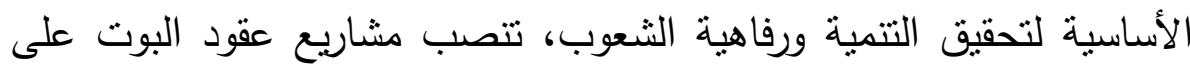

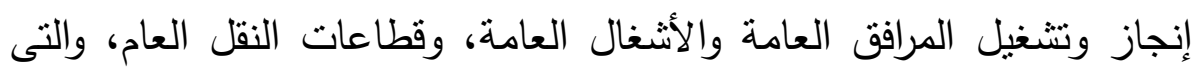
تدخل فى نطاق المجموعة الوطنية، باعتبار أن ملكية هذه المرافق تبقى تابعة ولفأ للاولة، وهى التى تسيرها عن طريق أجهزتها الإدارية.

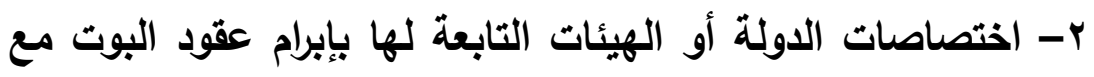

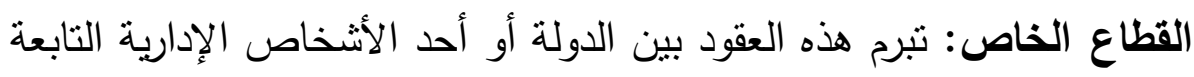

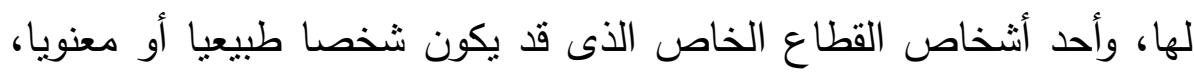

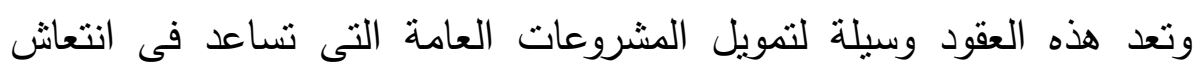
الاقتصاد وتعزيز التتمية.

وتظهر الدولة فى عقود البوت كجهة مانحة للترخيص أو الالتزام، وهى

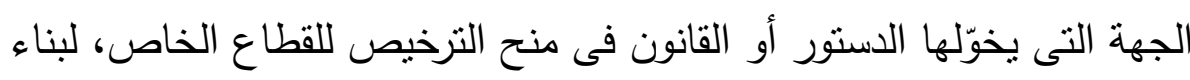

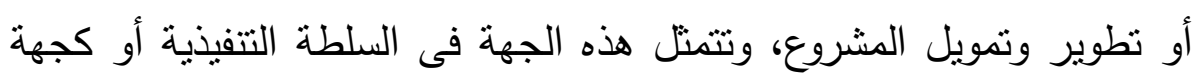
أو هيئة عامة فى اتفاق الترخيص، وهى عادة الهيئة المعنيّة أصلا بتتظيم 
المرفق وتقديم الخدمة المرنبطة به، وتعتمد السلطة المتعاقدة عند إبرامها لعقود

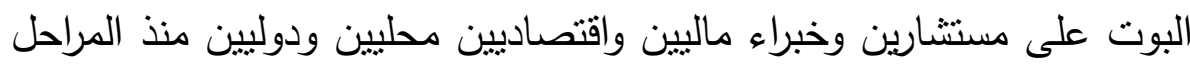

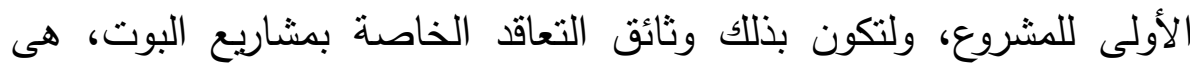
عقود الاستعانة بخبراء مستشارين لضمان أداء الخدمة العامة. r- غاية هذه العقود إنثاء مرافق عامة لتقديم خدمات ذات منفعة

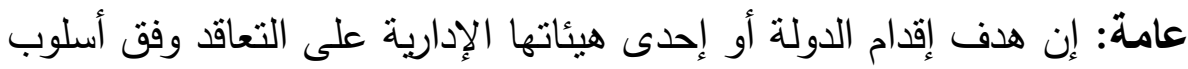

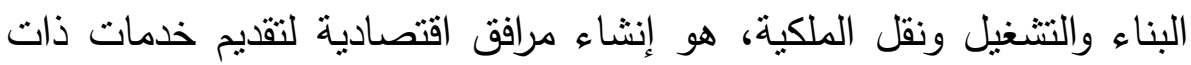
منفعة عامة لجمهور المنتفعين، ففى نتيبيد واستغلال هذه المرافق العامة،

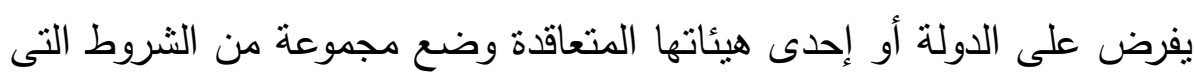
تضمن مراقبتها وتتفيذها فى كل المراحل. ؛ - التأكيا على إثراف الدولة على المرافق العامة المنجزة وفق عقود البوت: تخول للجهة الإدارية المتعاقدة بمهمة الإثراف والرقابة على شركة

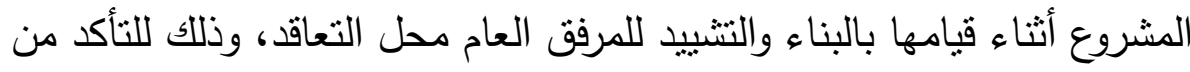
التزام الثركة المنجزة بالمواصفات المتفق عليها فى العقد، كما يخوّل العقد العداه

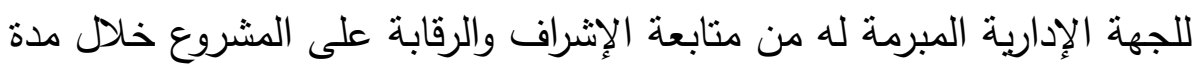

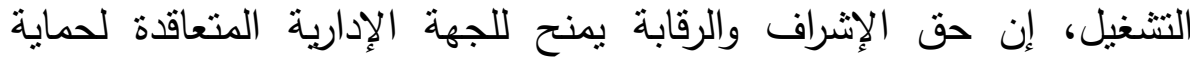

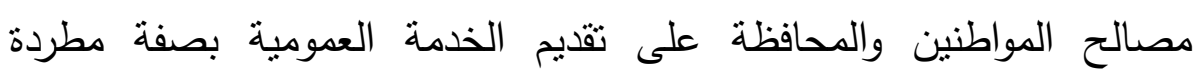
وبالمواصفات المنصوص عليها فى العقد. ه- ملكية الجهة الإدارية المتعاقدة للمرفق العام طيلة مدة التعاقد: تخول هذه العقود للإدارة المانحة لها من الاحتفاظ بحقى الملكية والتنظيم للمشروع، زيادة على حق الرقابة والإثراف طيلة مدة الامتياز ، أى أن هذه لهانه 
العقود تخول للإدارة المانحة حق الرقابة على التتفيذ والاستغلال، وذلك لضمان دوام سير المرفق العام بانتظام واطراد ومساواة المنتقعين من خدماته. צ- تخفيف العبء على الموارد المالية الحكومية المحدودة: فى هذه العقود يتحمل القطاع الخاص تمويل وإنثاء وتتشغيل هذه المرافق، وتحمل

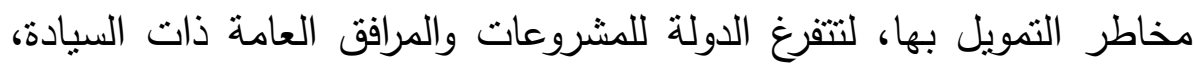

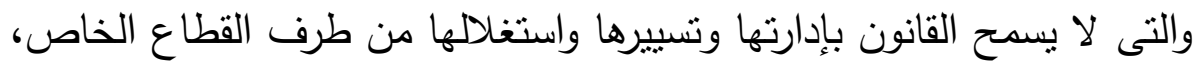

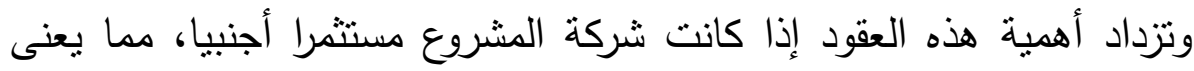

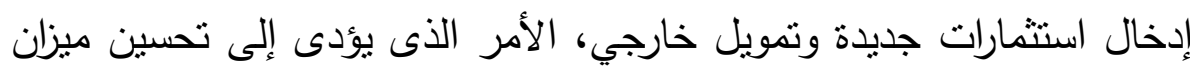

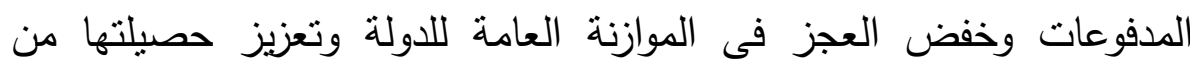

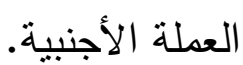
- V توفير البنية الأساسية المناسبة للتنمية الاقتصادية: إن عقود

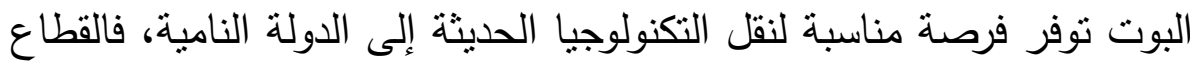

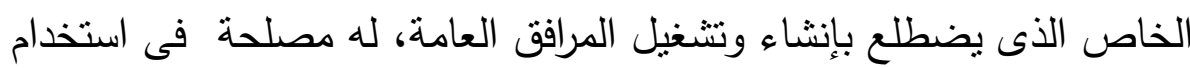

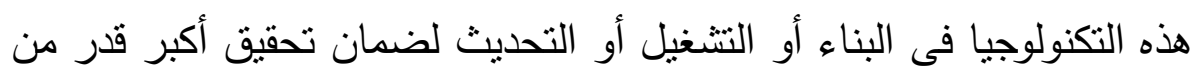

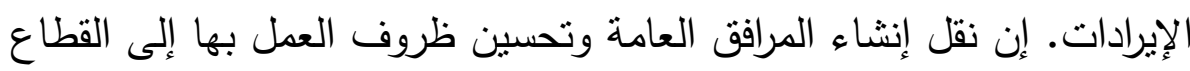

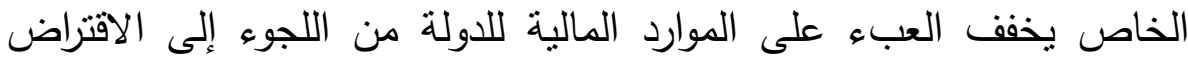

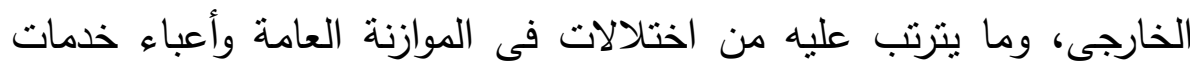

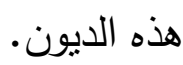

ᄉ- استفادة الحكومات من خبرة القطاع الخاص فى تقديم الخدمة العامة: فالإدارة الخاصة تحرص على الفاعلية والكفاءة أكثر من الإدارة الحكومية، مما يحسن من أداء الخدمة العامة وصورة الحكومة أمام المواطنين. 
9- ضمان تحقيق فرص العمل من إقامة المشروعات العامة: إذا

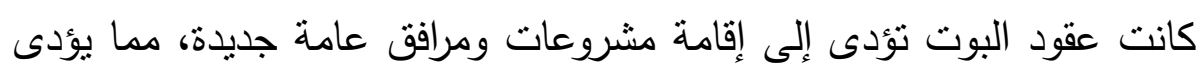

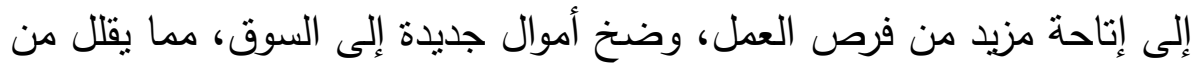

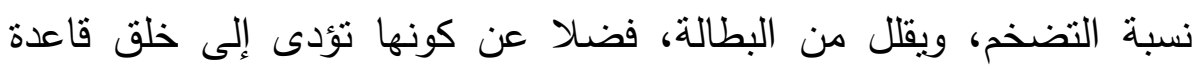

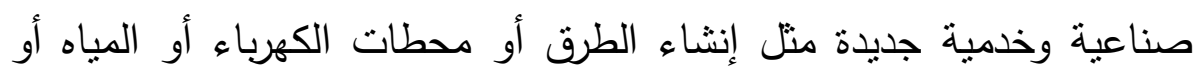
الإنفاق أو غيرها من المشروعات النى تتم عبر هذه العقود.

\section{ثالثا: صور وأشكال عقود البوت}

تعد عقود البناء والتتشيل ونقل الملكية الصورة الأكثر انتشارا لتنفيذ مشاريع

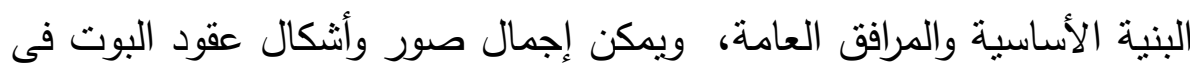
الآتى (rr) (الانته

- 1 عقود البناء وإلتملك والتثنغيل والتحويل (BOOT): هذه العقود

تتيح للمستثمر بناء المشروع وإقامة هياكله ومعداته وتملكه لفترة مؤقتة بواسطة

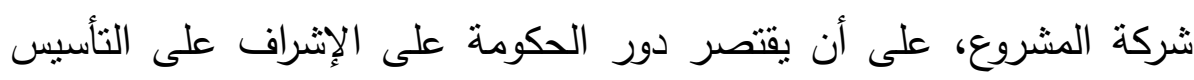

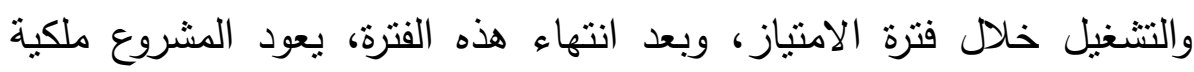

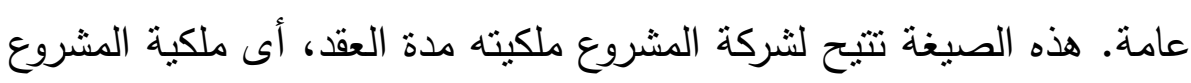

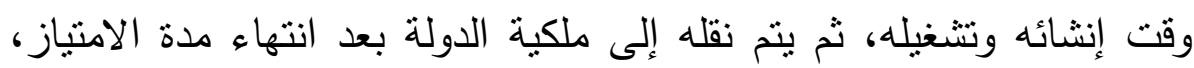

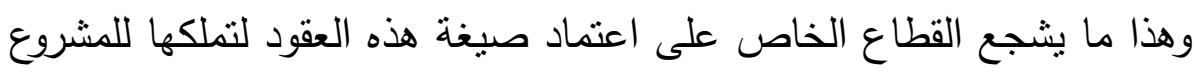

$$
\text { ولو لمدة محددة. }
$$

r- عقود البناء والتملك والتشغيل(BOO): هذه العقود تبرم بين

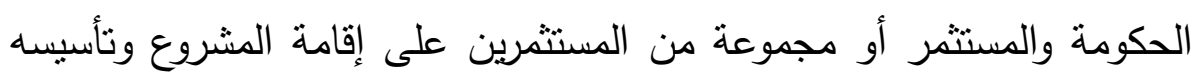

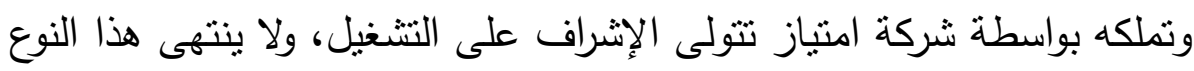
من المشروعات بتحويله إلى الملكية العامة، ولكن بعد انتهاء الفترة المحددة، 
يتم تجديد الامتياز أو انتهاء المشروع لانتهاء العمر الاقتراضى له، وفى حالة بقائه يتعيّن على الدولة تعويض الملاك عن حصص الملكية وفقا لتقييم أصول التهاه

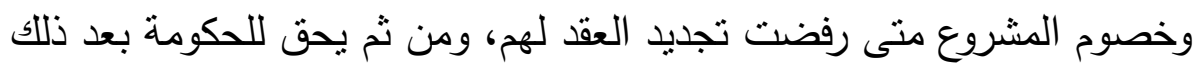
التعاقد مع آخرين على إدارة المشروع من خلال عطاءات مقدمة يتم اختيار

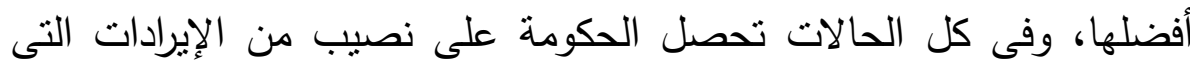
يحققها المشروع مقابل منح الامنياز ودعم المشروع أمام الجهات المختلفة. r- عقود البناء والتثشغيل وتجديد الامتياز(BOR): يتم هذا التعاقد على التى

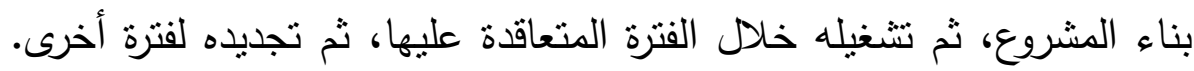

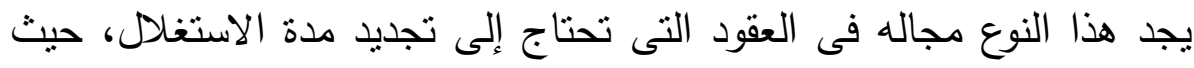

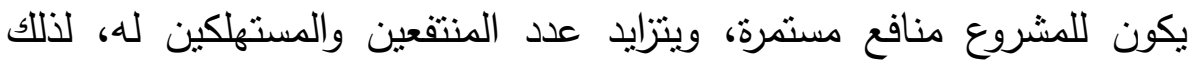
تدخل الدولة فى التفاوض مع المستثمر، لحصوله على فترة زمنية أخرى لتجديد

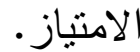

ع- عقود التصميم والبناء والتمويل والتثغيل (DBFO): تتفق الحكومة

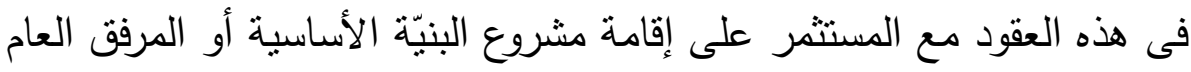

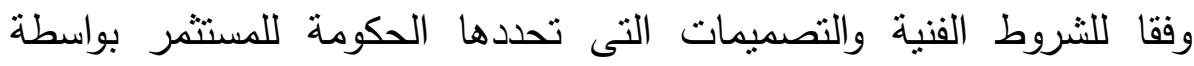
أجهزتها الاستثارية، على أن ينولى المستثمر المتفق مع الحكومة على إقامة

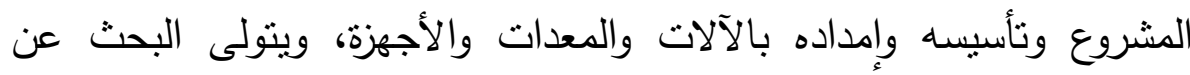

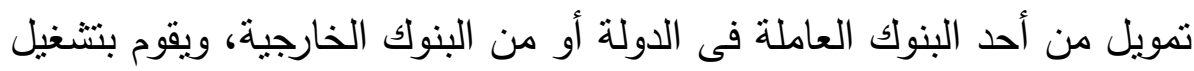

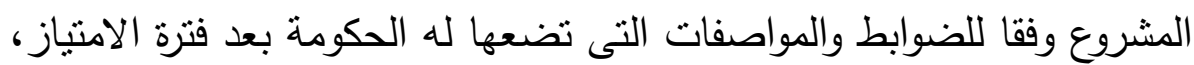

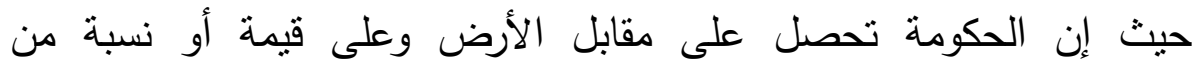

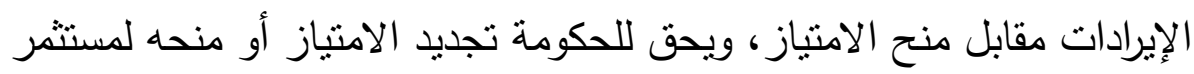

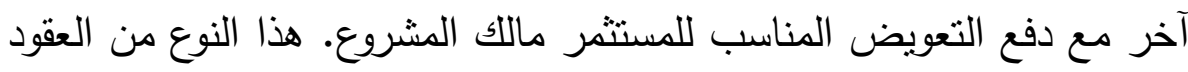


استعملته بريطانيا فى مجال الطرق السريعة، وذلك قبل تبنيها لعقود المبادرة

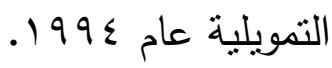

ه- عقود البناء والتتحويل وإلتشغيل (BTO): فى هذا النوع من العقود،

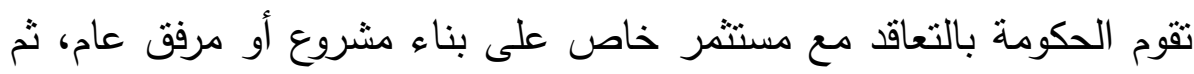

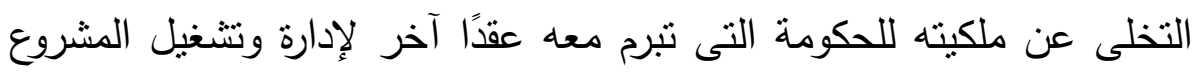

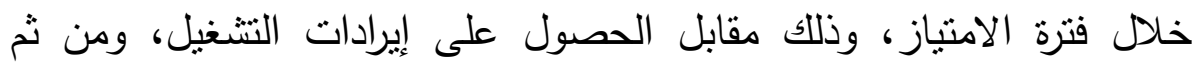
تصبح الحكومة هى المالكة للمشروع منذ البداية وهذا عكس العقود السابقة.

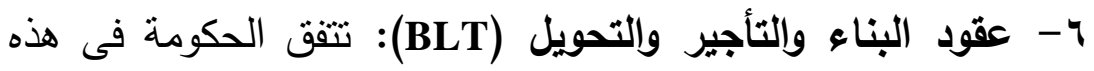
العقود مع مستثمر خاص لبناء مشروع أو مرفق عام وتأجيره له لفترة زمنية، يحصل خلالها المستتمر على إيرادات فى مقابل أن يؤدى للحكومة إيجار

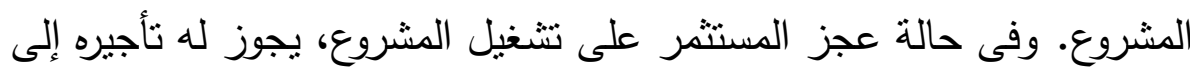
مستتمر آخر لإدارته ونتغيله خلال الفترة العقد.

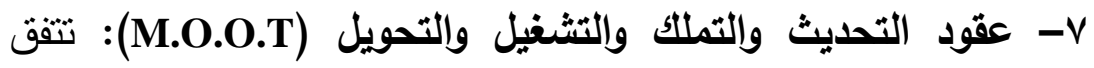
الحكومة مع المتعاقد على تطوير مرفق عام أو مشروع بنية تحنية قائم، وهذا

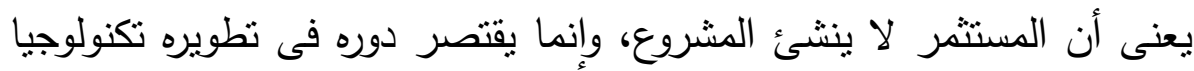

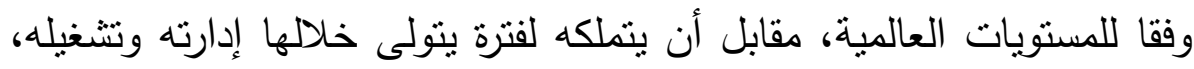

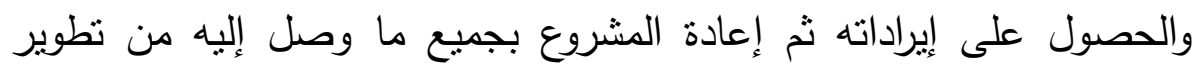
وحداته بعد نهاية فترة الامتياز إلى الحكومة دون مقابل.

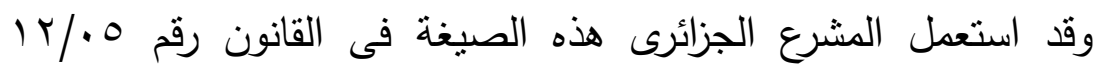

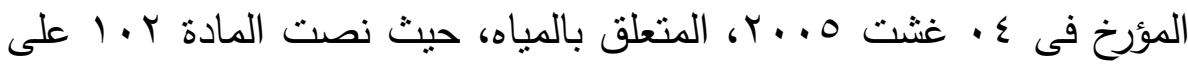
أن "يكلف صاحب امتياز بالخدمة العمومية للماء والتطهير فى إطار الحدود الإقليمية للامتياز، باستغلال المنشآت والهياكل التابعة للأملاك العمومية 
والاصطناعية للماء وصيانتها وتجديدها وإعادة تأهيلها وتطويرها .."، كما

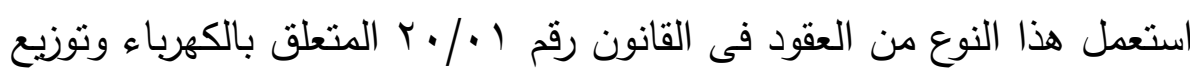

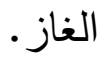

^- عقود التجديد والتملك والتثظيل (MOOT): تتعاقد الحكومة مع المستثمر الخاص من أجل تجديد أحد المشروعات العامة التى تحتاج إلى لنى

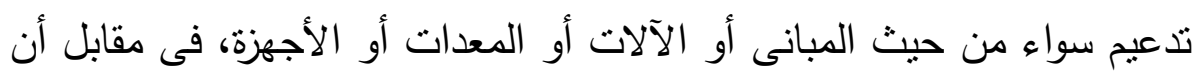

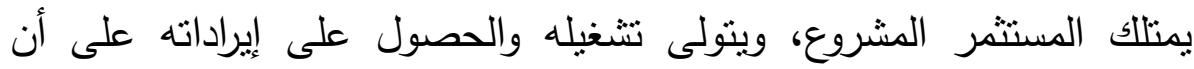
تحصل الحكومة منه على مقابل انتقال ملكية المشروع منها إليه،فى هذا النوع من العقود يقوم المستثمر باستئجار المشروع من الجهة المالكة له، ثم يقوم

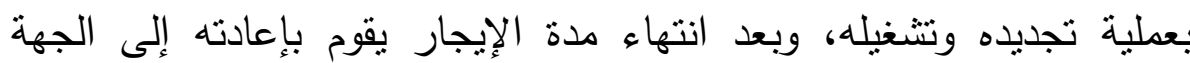

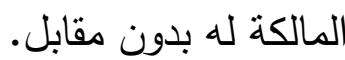
9- عقود البناء والتمويل والتحويل (B.F.T): يعتمد هذا النوع من

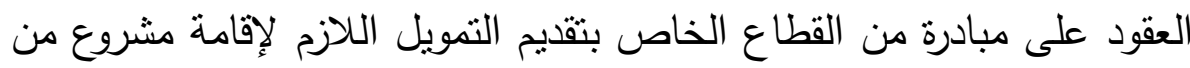

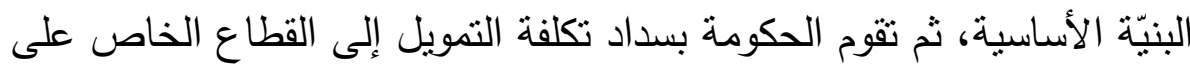

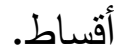
• 1 - عقد التأجير والتتريب والتمويل(L.T.T): يقوم القطاع الخاص فى التى هذه العقود بتمويل إقامة مشروعات وتدريب العاملين التابعين للاولة عليها، ثم

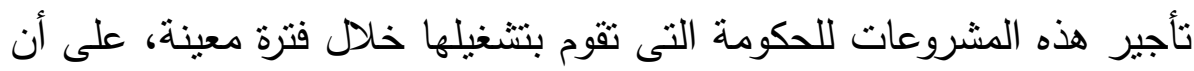
تعود ملكية المشروع إلى القطاع الخاص. |- إند التجهيز والتشغيل والتحويل (F.O.T): يقوم هذا العقد على التى

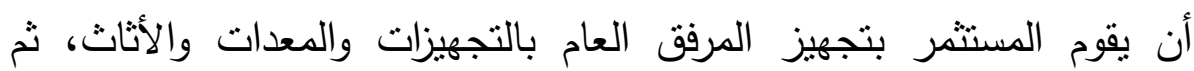
تتشغيله لمدة محددة مقابل حصوله على إيرادات ناتجة عن عملية التشغيل 
وتحقيق الأرباح، وعند انتهاء مدة العقد يعاد المرفق إلى الجهة الإدارية صاحبة

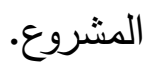
هذه أهم عقود البوت القائمة على مشاركة القطاع الخاص فى عملية إنثاء وتمويل وتنتييد المرافق العامة.

\section{المهور الثانى: الإطار القانونى لعقود البوت}

على الرغم من أن عقود البوت بأنواعها المختلفة انبثقت من عقود التزام المرافق العامة، وهذا ما جعل بعض الفقهاء يصرحون بأن هذه العقود ليست مستحدثة،

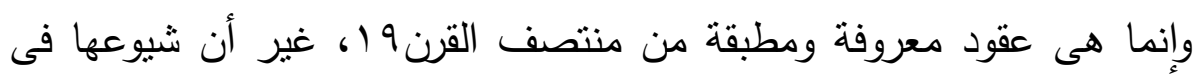

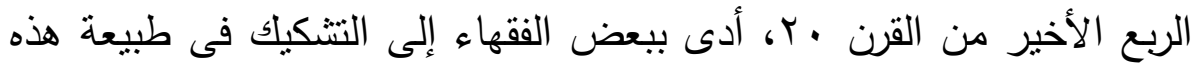
العقود، وهذا ما جعل الفقه يتتازع حول تكييف هذه العقود، فهناك من يعثبر

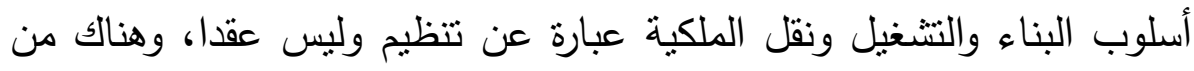
يضفى على هذه العقود صفة العقود الإدارية، وهناك من بعتبرها من قبيل عقود

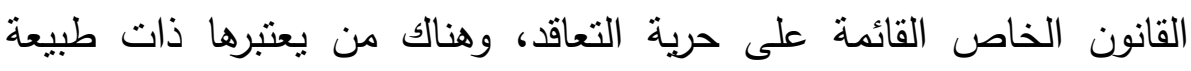

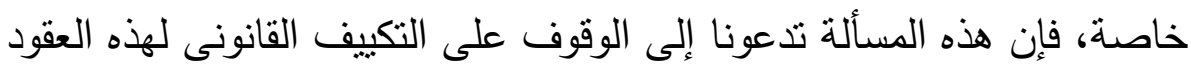
فى المطلب الأول، وبيان طرق و كيفيات إبرامها فى المطلب الثانى.

\section{أولاً: التكييف القانونى لعقود البوت}

قد تتازعت الآراء الفقهية فى التكييف القانونى لعقود البوت، وهذا ما نحاول

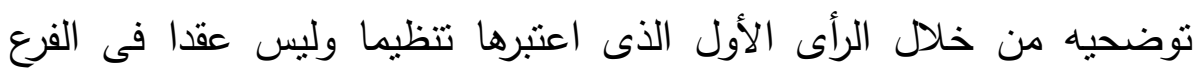

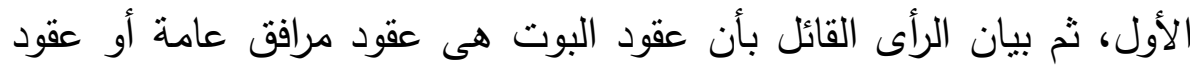
ذات طبيعة إدارية، وهذا ما نتتاوله فى الفرع الثانى، وفى الفرع الثى الثالث 
نستعرض الرأى القائل بأن عقود البوت ذات طبيعة خاصة، وفى الفرع الرابع نبيّن موقف القانون الجزائرى من تكييفه لهذه العقود.

\section{I - عقود البوت تنظيم وليست عقدا}

يرى جانب من الفقه على أن عقد البوت ليس اتفاقا وعقدا، أو إنما هو تتظيم

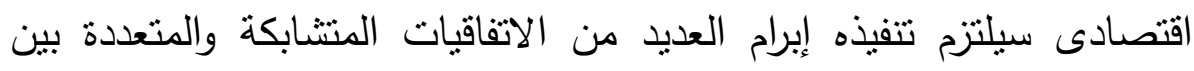

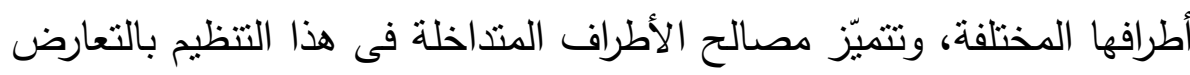

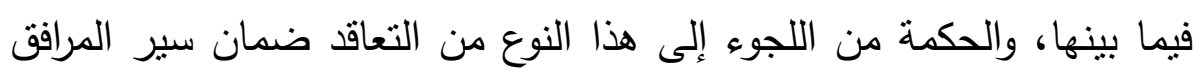
العامة باطراد فى أداء الخدمة العمومية للمواطنين.

هذا الاتجاه الفقهى ينكر الطبيعة الاتفاقية لعقود البوت، ويقرر طبيعتها

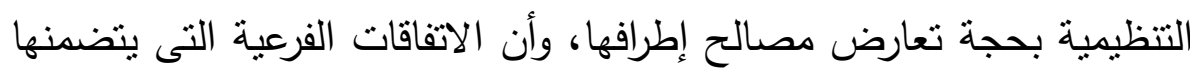

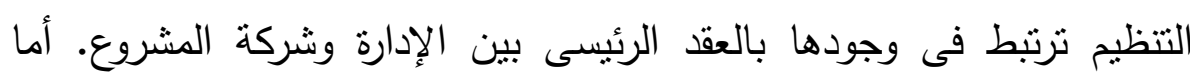

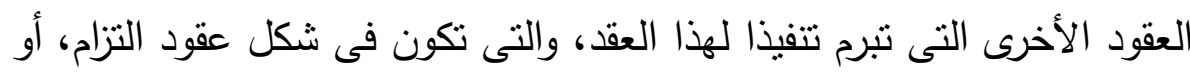

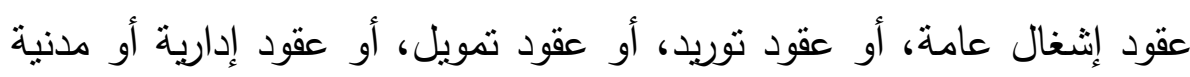

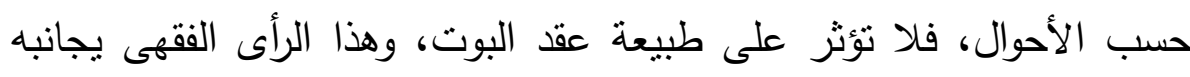
الصواب فى تحديد الطبيعة القانونية لعقود البوت.

\section{r- عقود البوت ذات طبيعة إدارية}

يرى أنصار فقه القانون العام أن عقود البوت هى عقود إدارية، وما هى إلا إلا

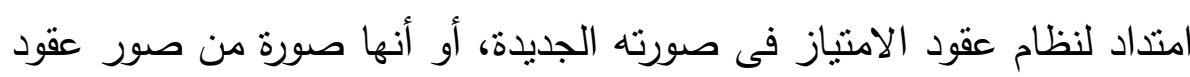

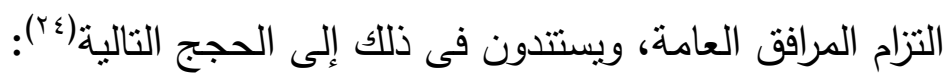
أ- عقود البوت هى عقود قديمة، أبرمت فى صورة مستحدثة لعقود التزام 
ب- خضوع هذه العقود لمعايير وشروط العقود الإدارية، من هذه المعايير: - أن يكون أحد طرفى العقد شخصا من أنخاص القانون العام. - أن يتعلق محل التعاقد بمرفق عام. - أن يتضمن العقد شروطا استثنائية غير مألوفة فى عقود القانون الخاص (ro) (10. ج- موضوع وأهداف عقود البوت تخضع لأحكام القانون العام: إذا كان موضوع وأهداف عقود البوت تتصب على إنثاء وتجديد مرافق عامة وإدارتها

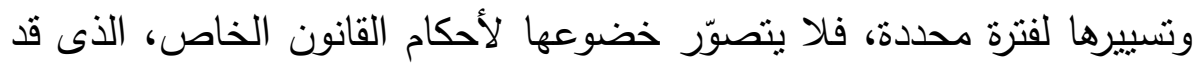

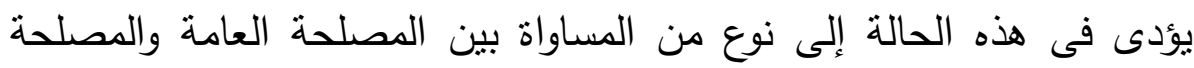

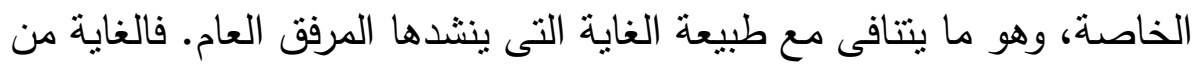

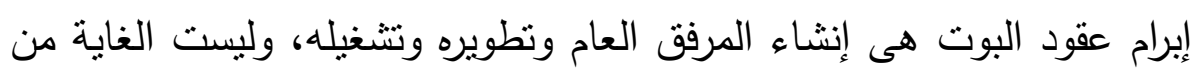

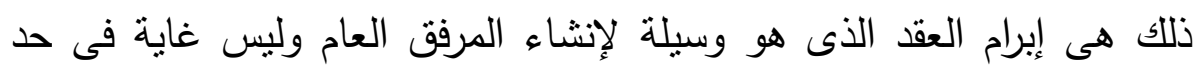
ذاته.

د- احتواء عقود البوت على شروط استثنائية لا يتنفى عنها الطبيعة

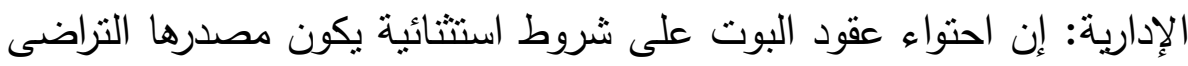

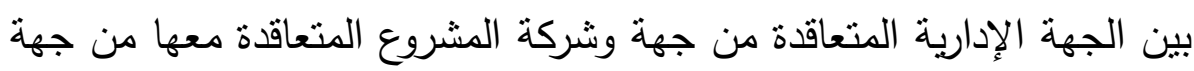
ثانية، والتخفيف من الثروط اللائحية لا ينفى عن هذه العقود طبيعتها الإدارية،

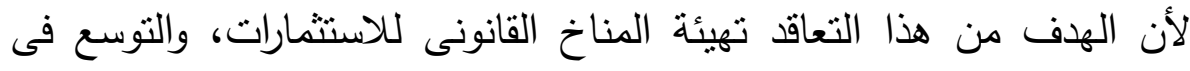

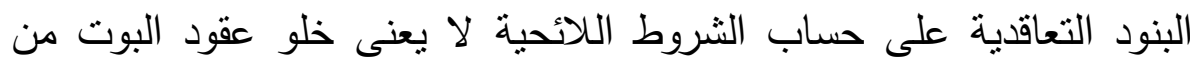

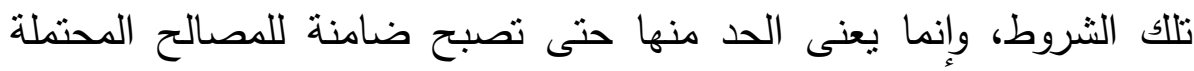
للمستثمرين وغير مضر بالمصلحة العامة. 


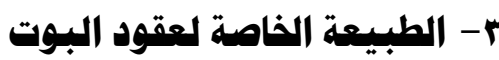

ذهب اتجاه فقهى إلى أن عقود البوت هى من عقود الإدارة العادية التى تخضع

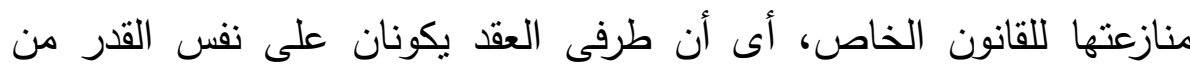

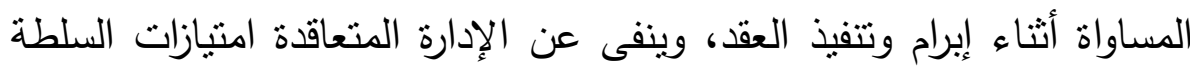

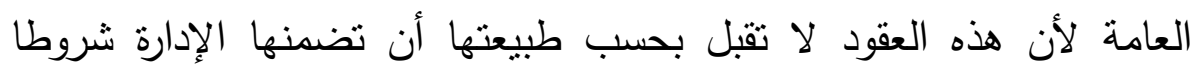
استثائية ، فمنطلبات التجارة الدولية تقرض على الدولة أن نتزل فى تعاقدها

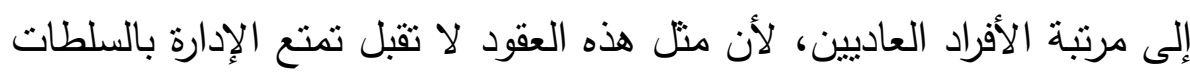

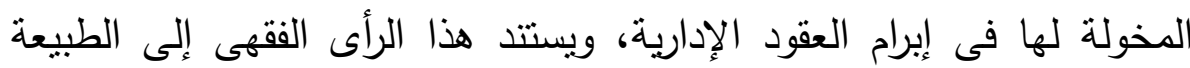
الخاصة لعقود البوت على الحجج التالية(؟r): أ- اختلاف أسلوب التعاقد بين عقد البوت وعقد التزام المراقق العامة: وأساس هذا الاختلاف يكمن فى كون عقد التزام المرافق العامة هى عقود إدارية

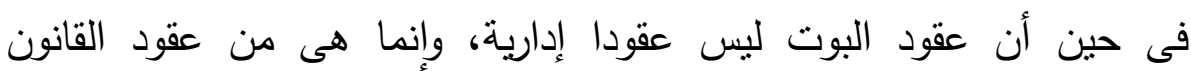

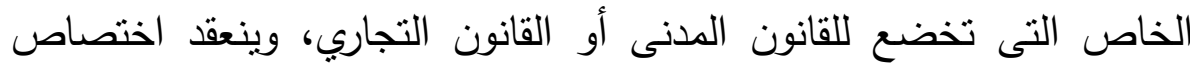

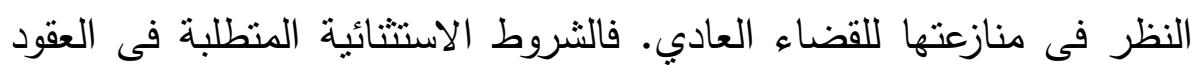
الإدارية، وهيمنة امنيازات السلطة الإدارية على العقد الإدارى غير متوفرة

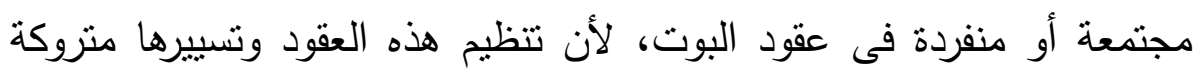

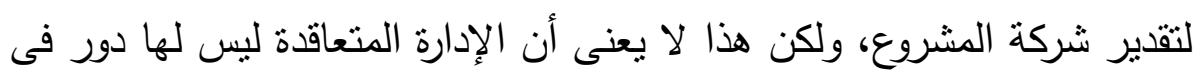

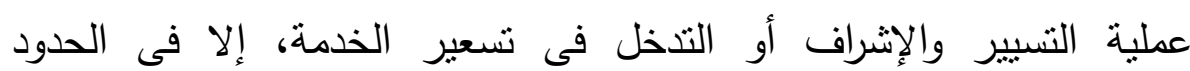
المنصوص عليها فى العقد.

ب- قيام عقود البوت على مبدأ العقد شريعة المتعاقدين: أى أن التعاقد وفق هذا الأسلوب يحكمه مبدأ سلطان الإرادة الذى يعد من عقود القانون

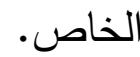


ج- عدم خضوع عقود البوت لمعايير وشروط العقود الإدارية: فوجود

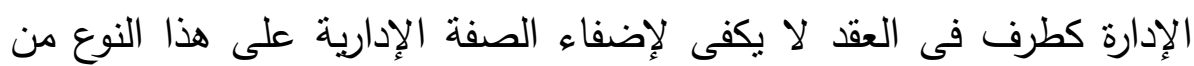

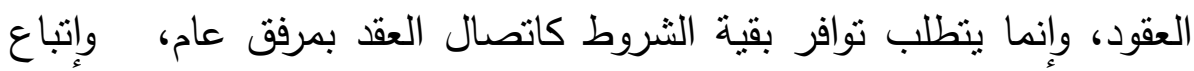

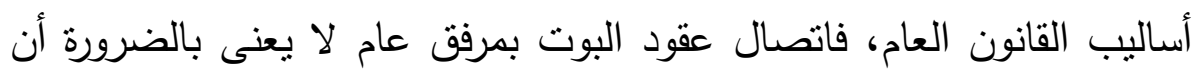
يكون العقد إداريا، وذللك للأسباب التالية:

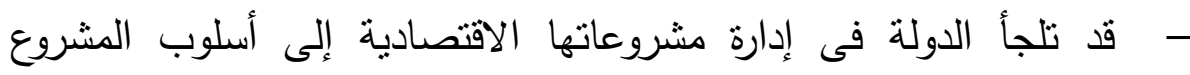

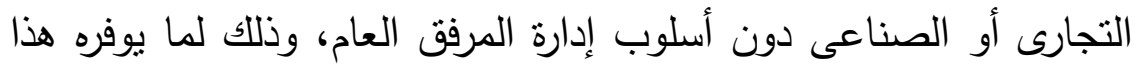

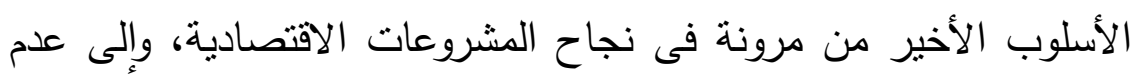

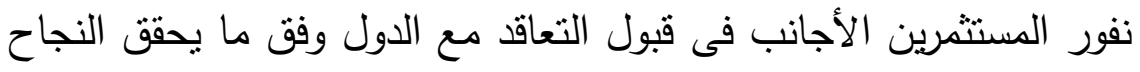

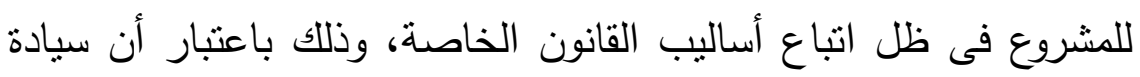

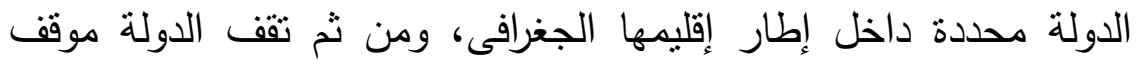
المساواة مع الطرف الأجنبى المتعاقد معها. - التعاقد وفق أسلوب البوت لا يتصل فى جميع الأحوال بمرفق عام، وإنما يتصل بمشروعات استثمارية تهلف إلى تحقيق مصالح خاصة، ومثال ذلك عقود إنثاء مشروعات سياحية (فنادق) نستثمر فيها الدولة مواردها المالية بغرض بيع الخدمة، وهذا ما يرتبط بالقانون الخاص أكثر من القانون العام.

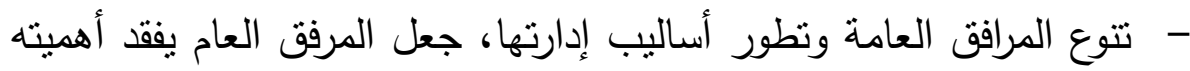
كمعيار لتحديد اختصاص القضاء الإدارى. - عقود البوت تجرد الجهة الإدارية من احتواء عقودها على شروط استثنائية

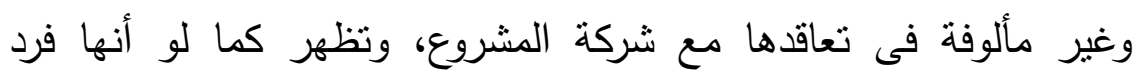

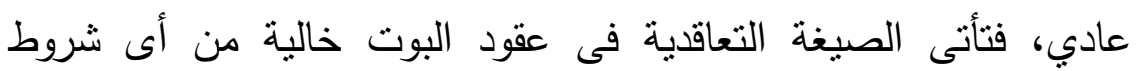

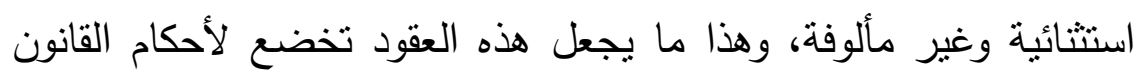


المدنى أو التجارى وغير خاضعة لمواصفات التعاقد وفق أحكام القانون العام.

د- تمسك الدولة بأحكام القانون العام كأساس لتكييف عقود البوت يحرم الدول النامية من الاستثمارات: التى تسهم فى نقل التكنولوجيا وزيادة

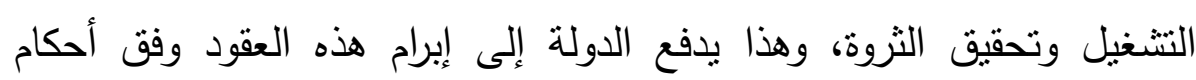
القانون الخاص كأساس قانونى لها. هـ إن طبيعة العقد الإدارى تتعارض مع ملكية شركة المشروع: تعد المدان

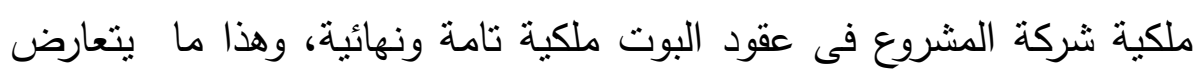

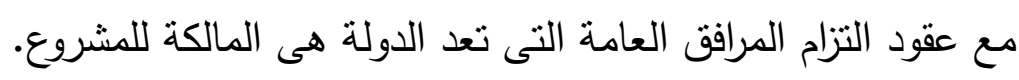

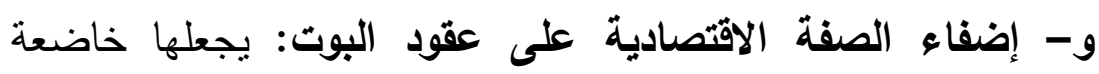

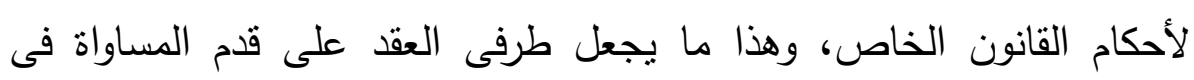

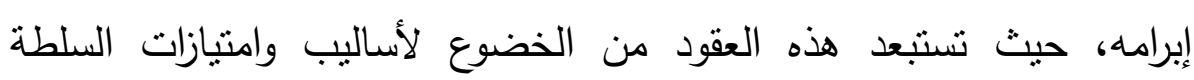
العامة، وهذا يمنع تطبيق أحكام وقواعد المرافق العامة على عقود البوت لنباين القانون المطبق على كل منهما. ز- نزول الاولة عن ملكية المشروع فى عقد البوت وعن ملكية الأرض المثل

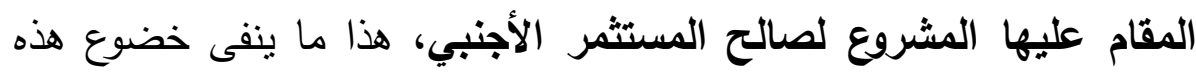

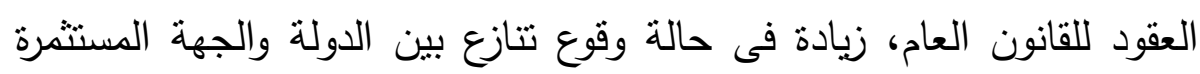

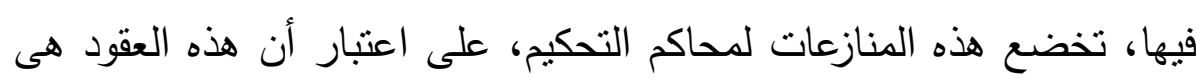

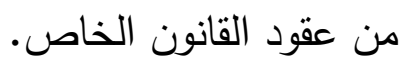

\section{§- التكييف القانونى لعقود البوت في القانون الجزائرى}

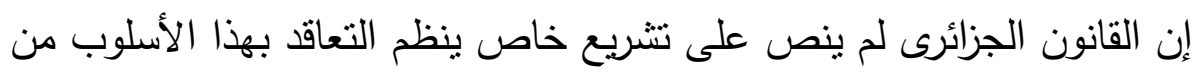

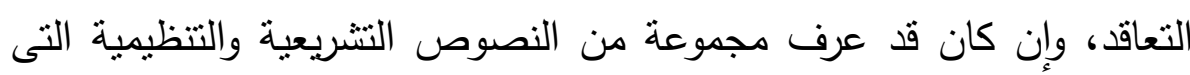


أنثارت إلى هذه الطائفة من العقود، وذلك من خلال إحاقها بعقود الامتياز،

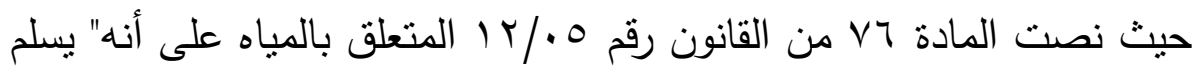

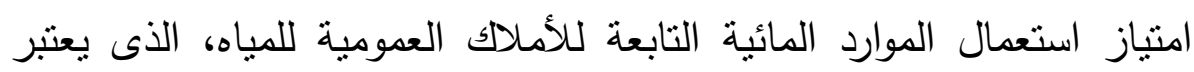
عقدا من عقود القانون العام لكل شخص طبيعى أو معنوى خاضع للقانون

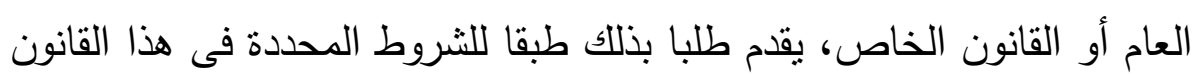
والكيفيات التى تحدد عن طريق التنظيم".

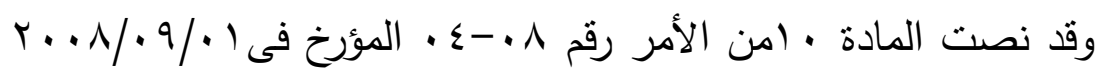

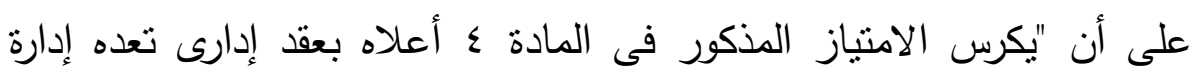

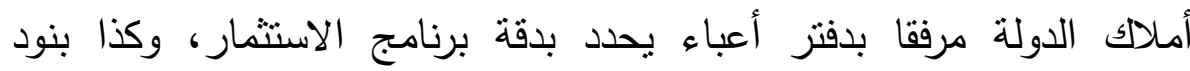

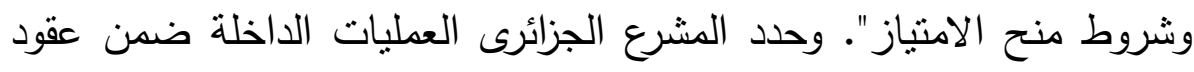

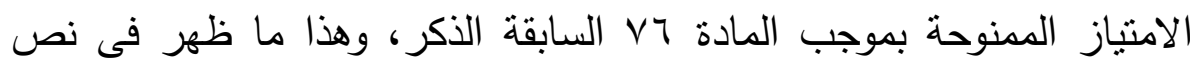

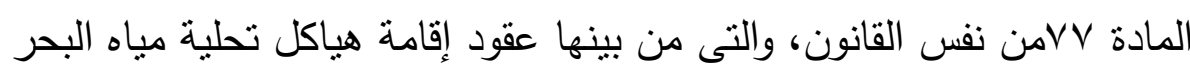
أو نزع الأملاح والمعادن من المياه المالحة من أجل المنفعة العمومية أو تلبية الاحتياجات الخاصة. فهذه العقود بناء على النصوص القانونية السابقة تبرم وفقا لقواعد القانون العام، وذللك لاحتوائها على خصائص ومميزات العقود الإدارية.

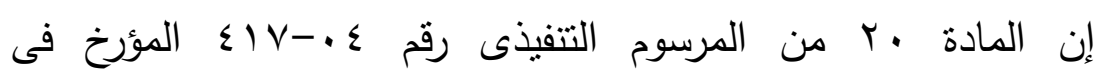

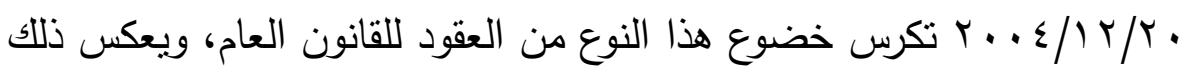

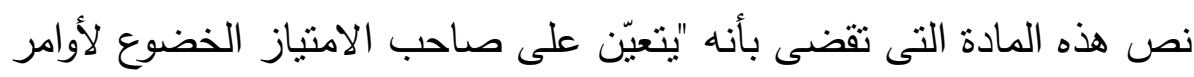

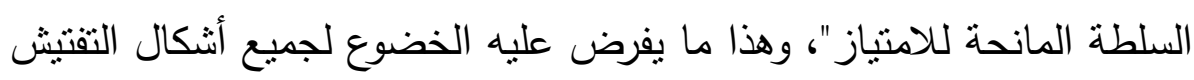
والمراقبة التى تقوم بها الجهة المانحة سواء بطريقة دفاجئة أو بصورة منتظمة. 
كما قررت المادة جr من نفس المرسوم التنفيذى إمكانية سلطة الامتياز إلغاء عقد الامتياز للأسباب التالية: - إذا لم تتوفر الثروط التى سمحت بالحصول عليه.

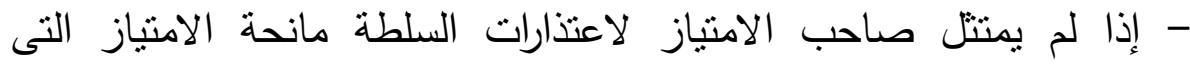
لاحظت مخالفة خطيرة.

- إذا كان صاحب الامنياز يستغل الامنياز فى ظروف مختلفة عن تلك الواردة

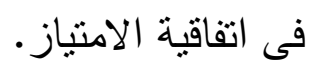
- إذا خالف صاحب الامتياز أحكام هذا المرسوم بشكل خطير ".

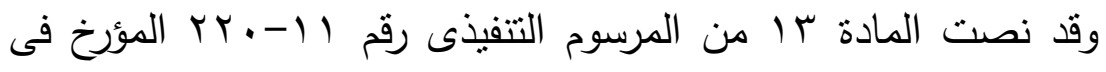

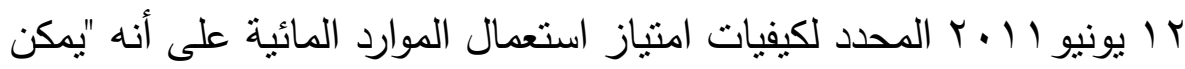

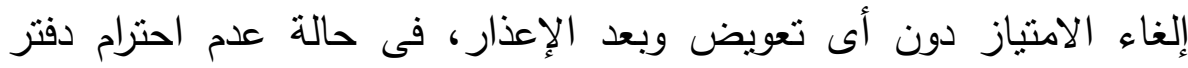

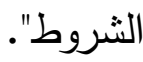

من خلال النصوص السابقة يتضح نوافر خصائص العقود الإدارية فيما يتعلق بعقود البوت فى القانون الجزائرى، ويظهر ذلك بصورة جلية فى جعل بل

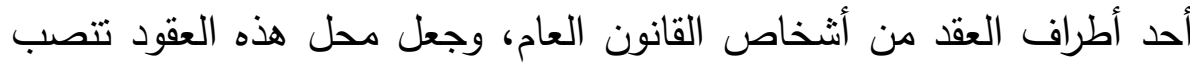
على إنشاء مرافق عامة لتحقيق المصلحة العامة، بالإضافة إلى احتواء هذه

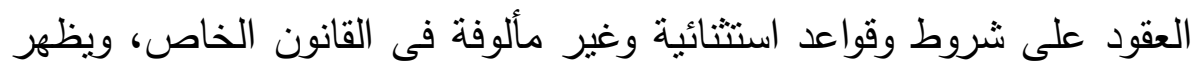
ذللك فيما يتعلق بسلطة التنظيم وسلطة الرقابة على إنجاز هذه واعدئ الهياكل ورقابتها.

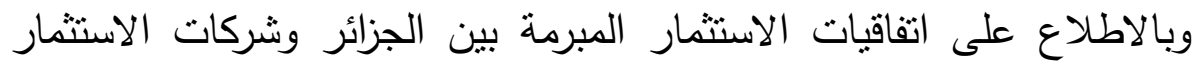

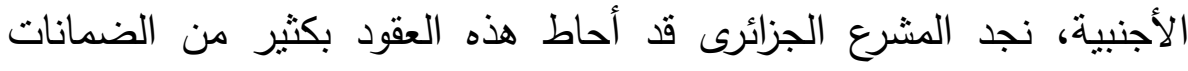
والتحفيزات المستمدة من قواعد قانون تطوير الاستثار، الخاضعة للقانون الخاص أكثر من خضوعها للقانون العام (^r). 
وقد لجأت الدولة الجزائرية من خلال تعاقدها مع المستثمرين الأجانب

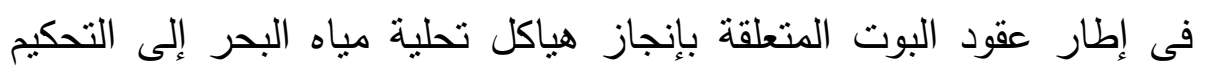

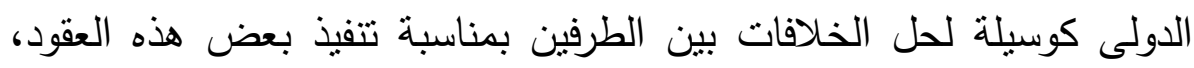

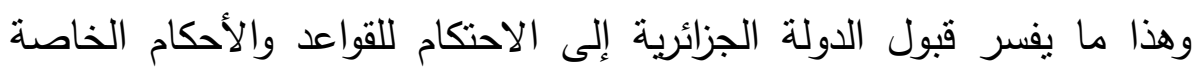

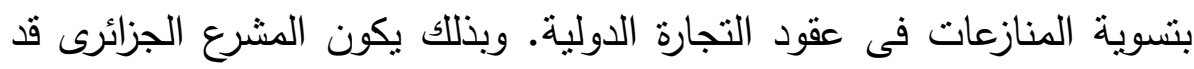
جعل الأصل فى تكييف عقود البوت المتعلقة بإقامة هياكل تحلية مياه البحر

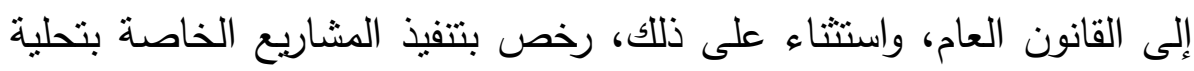

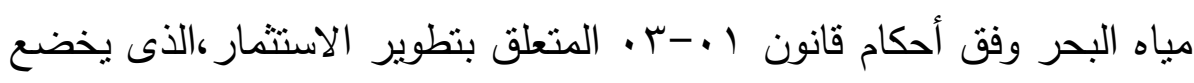
لأحكام وقواعد القانون الخاص.

\section{r- طرق وكيفيات إبرام عقود البوت}

نظرا لتعلق عقود البوت بالمرافق العامة المرتبطة غالبا بمشاريع البنية

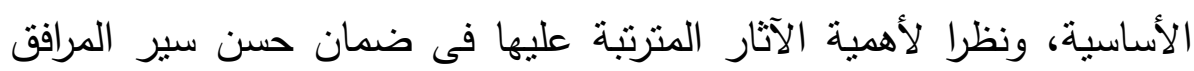

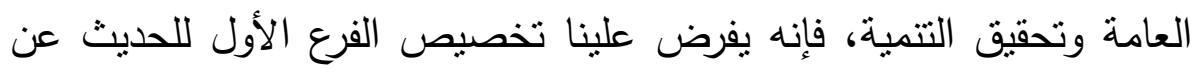

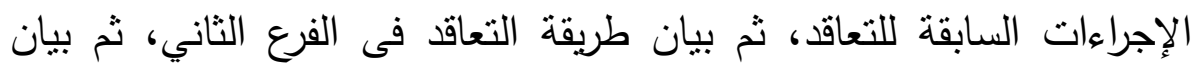
كيفية إعداد مشروع عقد البوت فى الفرع الثالث.

الفرع الأول: الإجراءات السابقة للتعاقد

تتمثل الإجراءات السابقة على التعاقد فى تحديد الدولة طبيعة المشروع التى

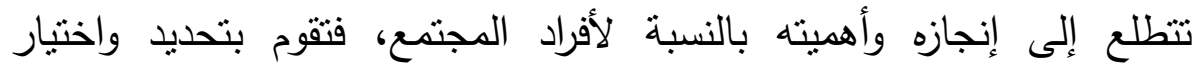

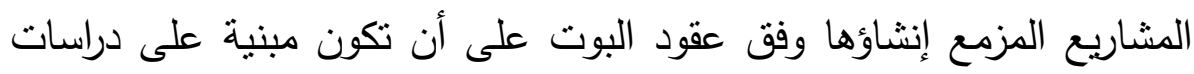

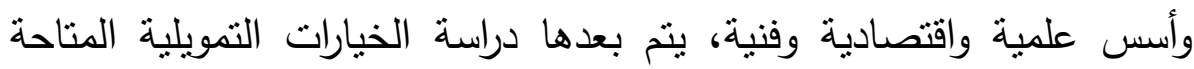
لإقامة المشروع المحدد، وتحديد الصيغة التعاقدية الملائمة. 
وغالبا ما تقوم الدولة بتحديد المشروع المطلوب إقامته وأسلوب نمويله، ولكن هذا لا ينفى إمكانية قيام شركة المشروع أو مجموعة من المستثرين

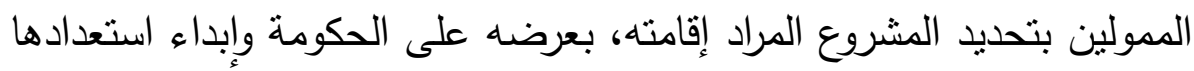
لتمويله وفقا لنظام البوت، فى هذه الحالة يحرص المستثمر على تحديد المشروع الذى يتوقع أن بحقق له نسبة عالية من الأرباح أو إحدى هيئاتها لهاه

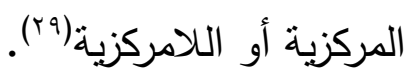

فالدولة هى الجهة الإدارية مانحة الامتياز والمالكة الحقيقية

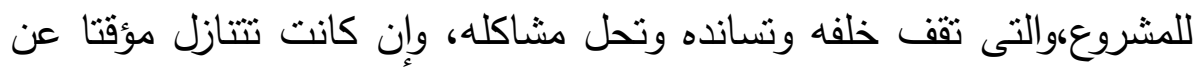
تللك الملكية للمستثر من أجل إقامة مشروع معيّن ينتفع به لفترة من الزمن ثماند

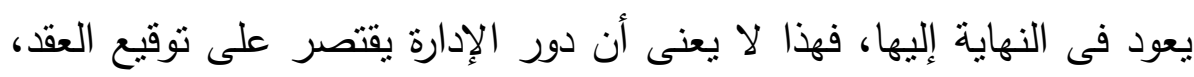
وإنما مهمنها تظل قائمة فى كالأتى (r.): - متابعة عمل الثركات والتأكد من جلية التزامها بالتنفيذ: وذلك فئل

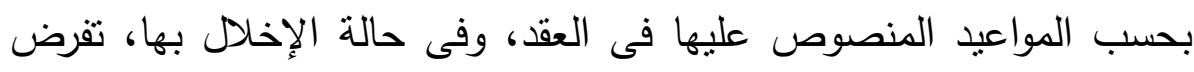
العقوبات المالية كالغرامات المتفق عليها أو مصادرة مبالغ الضمانات. - متابعة عمليات الإنشاء والتأكد من جودة المنشئ ومطابقته المواد الداد المستخدمة للمواصفات القياسية: - المتابعة الدورية وإلتفتيش الرقابى على حسن سير المشروع، وذلك

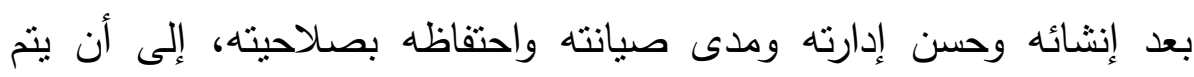
تسليمه إلى الجهة الإدارية المانحة له. أما الطرف الثانى فى التعاقد وهو الذى يقع عليه تصميم وبناء وتتغيل الأديله

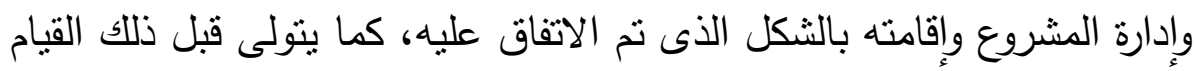
بالعديد من عمليات التفاوض التى تتم على النحو التالى: 
- التفاوض مع الجهة الإدارية المانحة للحصول على الامتياز وحق

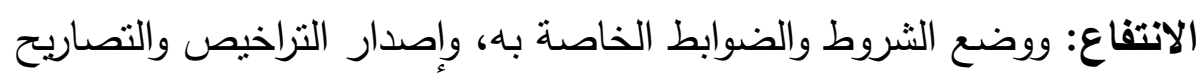
وتحديد الحقوق والواجبات بصورة دقيقة.

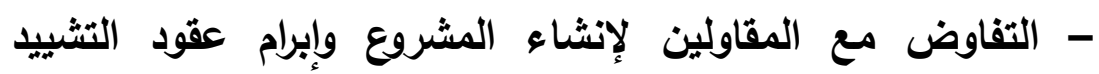

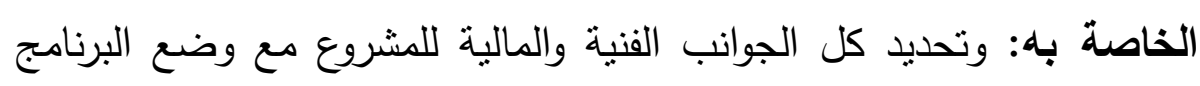

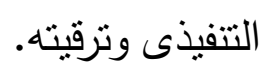

- التفاوض مع الموردين لتوريد مستلزمات التثنيل المختلفة للمشروع وإبرام العقود الخاصة بها.

- التفاوض مع شركات متخصصة لتشثيل وإدارة المشروع وصيانته والإثراف على كل جوانبه. - التفاوض مع البنوك الممولة للحصول على القروض والتسهيلات المختلفة وإبرام العقود الخاصة بها.

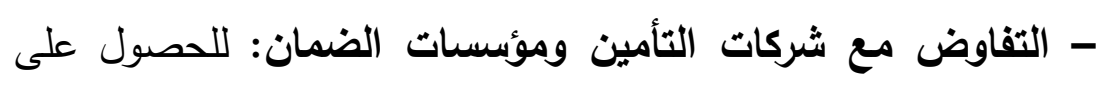

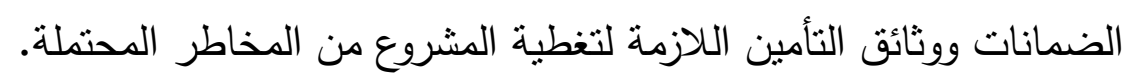

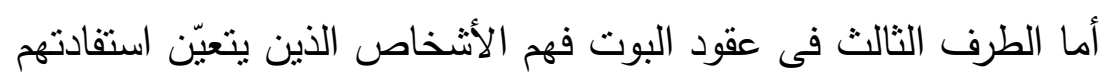

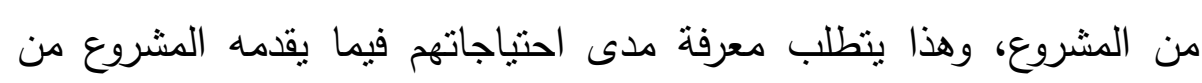
خدمات، ومعرفة مدى تناسب الخدمة مع الرسوم المقدرة لهذه الخدمة.

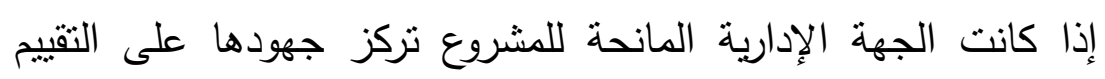

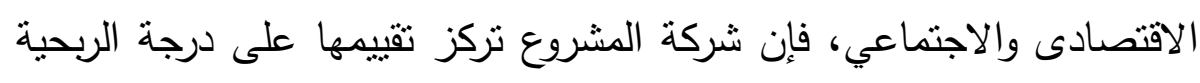

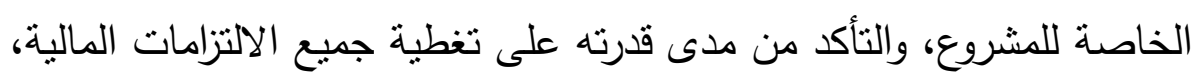
بما فيها خدمة الدين والأرباح، بالإضافة إلى تحديد الفجوات المالية التى ينعيّن 
على الجهة المانحة التنخل لتغطيتها، بتقديم بعض المزايا والضمانات من

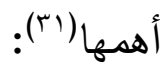
أ- تقديم مساهمة مالية كنحة أو قرض بفائدة منخفضة، أو الدخول كشريك

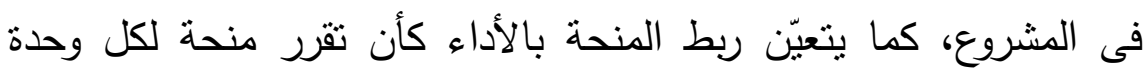

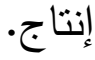
ب- تخفيض درجة المخاطرة من خلال بنود العقد النى تحمى المستثمر من

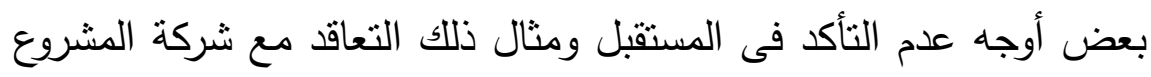

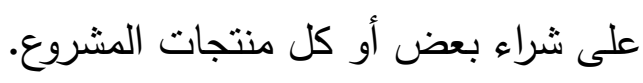

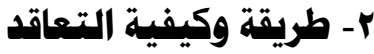

تبرم عقود البوت وفق جملة من الإجراءات من أهمها (rكاتهات:

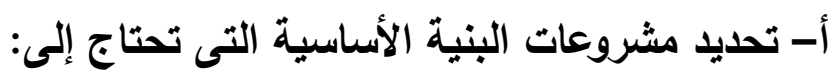

$$
\text { أ- تمويل من القطاع الخاص: }
$$

- تقوم الجهة الإدارية المانحة بتحديد المرافق العامة التى تعانى من سوء

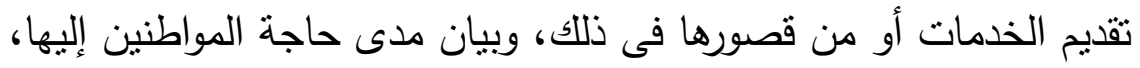

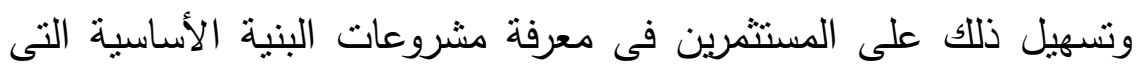
تحتاج إلى تمويل القطاع الخاص. - متتشئ الجهة الإدارية المانحة لتحقيق الغرض السابق، إما مؤسسة مستقلة تسهر على دراسات الجدوى لمتل هذه المشروعات، بحيث نكون نلك الكي المشروعات تحت إدارة وتسيير المستثمرين ومؤسسات التمويل عند الحاجة.

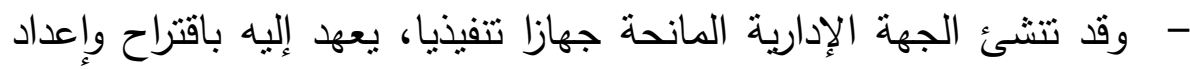
دراسات الجدوى عنها، بالإضافة إلى إعداد مشروعات القوانين واللوائح اللازمة لتحقيق قبول المشروع من قبل المستثمرين ومؤسسات التمويل. 
- تحديد مجالات مشروعات البوت وفق قوانين صادرة عن السلطة التشريعية نبيّن مجالات إبرام عقود البوت، بحيث لا تترك هذه المجالات لتقدير السلطة التنفيذية أو لرغبات مؤسسات التمويل دون ارتباط ذلك بالسياسة العامة للتتمية للادولة. ب- طرح المشروع واختيار المستثمر: تعتبر عقود البوت فى الجزائر من العقود الإدارية التى تخضع لقانون الصفقات باعتبار القانون الأساسى فى بيان كيفية إبرام عقود الإدارة المختلفة التى تخضع للقواعد والإجراءات المتطلبة فى الإديه اختبار صاحب المشروع فى إطار المناقثنة العلانية، ويتم ذلك بواسطة الإعلان المسبق، مع تحديد وثائق التعاقد ودفتر الثروط المتضمنة للمواصفات الثقنية والمالية اللازمة لإبرام العقد، وذلك من خلال:

- إعلان عن المناقصة: يعتبر إجراء جوهريا، والذى يتم بمقتضاه نوجيه الدعوة إلى كل المقاولين والمتعاهدين الراغبين فى التعاقد مع الإدارة، مع بيان

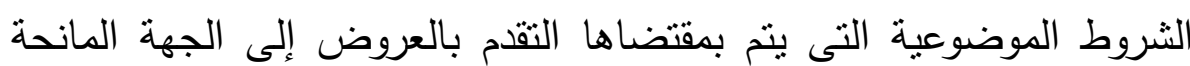

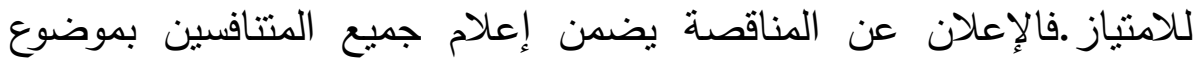
المناقصات والمزايدات العامة، حتى يتسنى لهم التقام بعطاءاتهم فى الوقت الته

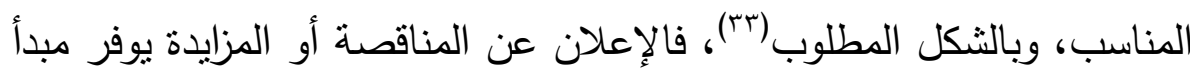
المساواة بين المتتافسين، وعلى أن يعامل جميع المشتركين معاملة متساوية

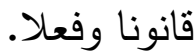

- تقديم العطاءات: إن طرح العطاء ينطلب تحديد وثائق المناقصة، ثم

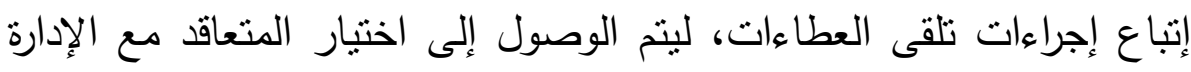

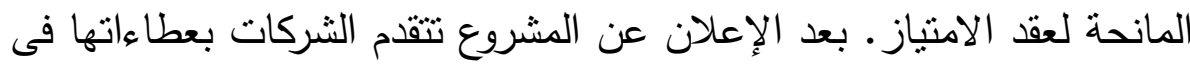

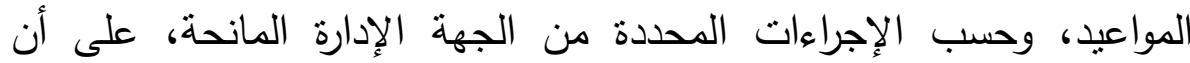


يتضمن العطاء تحديد مصادر تمويل المشروع بموجب خطة تمويلية، تحدد تلك

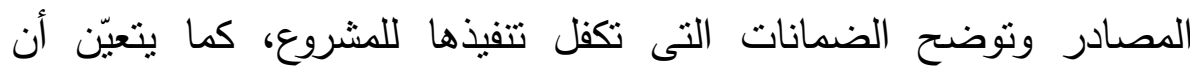
تتضمن العطاءات الرسومات الخاصة بالشروع وكيفية تتفيذه، وآجال التنفيذ،

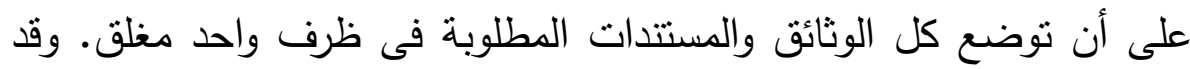
نصت على ذلك المادة r/01 من قانون الصفقات العمومية الجزائرى على

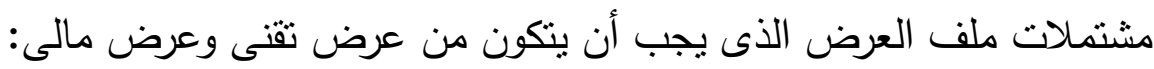
- تقييم العطاءات واختيار المتعاقد: بعد تلقى العروض من قبل لتيل المتعهدين، تقوم لجنة فحص العروض بمراقبة الوثائق والعروض المقدمة،

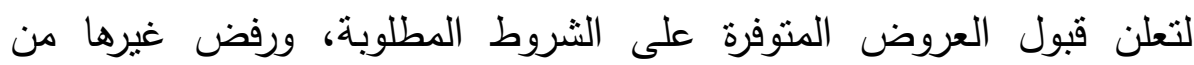
العروض غير مكتملة شروط. ثم تعود هذه اللجنة إلى دارسة الاقتراحات وتقييمها لاختيار أفضلها، ويتعيّن أن تتم هذه العملية وفقا للقودوداعد والأحكام

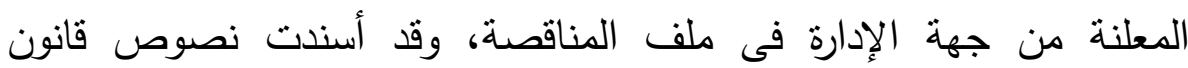
الصفقات العمومية الجزائرى مهمة فحص العروض إلى لى لجنتين هما، لجنة فتح

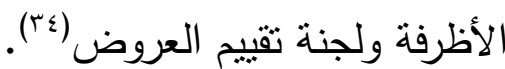

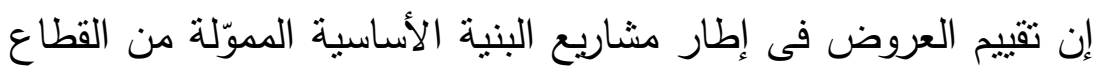

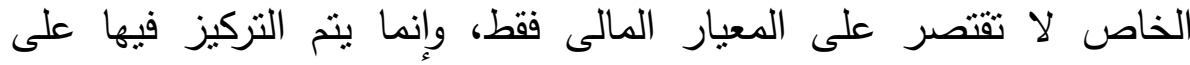
المعايير الفنبة والتقنية للمشروع، من حيث التكلفة ونوعية التكنولوجيا المستخدمة ووفرة الصرف الأجنبى، والعمالة المستخدمة، وشروط التمويل الترايله ومصادره.

وبعد انتهاء الجهة الإدارية المانحة للمشروع من تقييم العروض وإبداء موافقتها على إرسائه وقيام الاتحاد المالى لهذه المجموعة بتكوين شركة الإنهاه

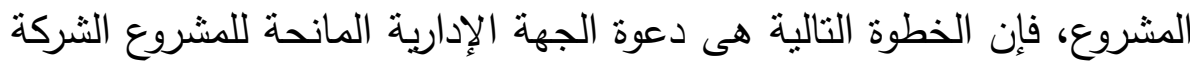


التى تقدمت بأفضل عرض لتوقيع عقود ومستتدات تتفيذ المشروع، وذلك بعد

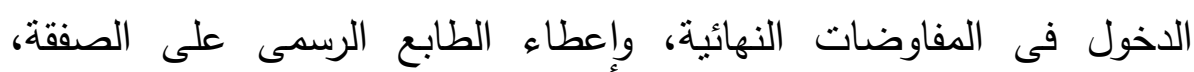
والإعلان عن إنمام إجراءاتها.

المحور الثالث: الآثار القانونية لعقود البوت تعتبر عقود البوت من العقود الملزمة للجانبين، والمرتبة لحقوق والتزامات متقابلة فى ذمة أطرافها، فهناك حقوق والتزامات تقع على الإدارة المتعاقدة،

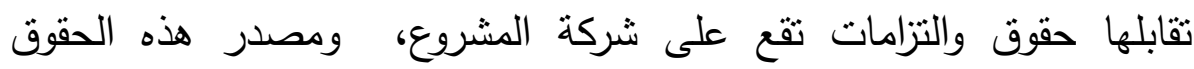
والالنزامات القاعدة القانونية النى تتص على على أن العقد شريعة المتعاقدين، فى

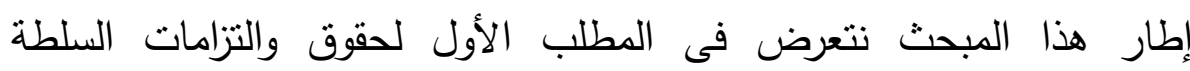
المتعاقدة، وفى المطلب الثانى نبيّن الحقوق والالنزامات الواقعة على شركة

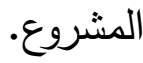

أولا: حقوق والتزامات السلطة المتعاقدة ترتب عقود البوت بعض الالتزامات على الجهة الإدارية المتعاقدة من جهة،

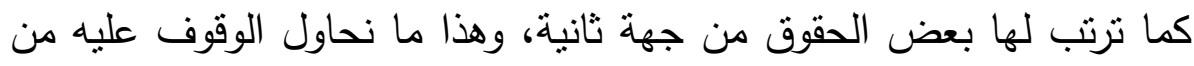

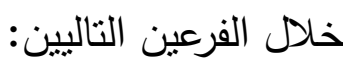

1- التزامات السلطة المتعاقدة من الالنزامات التى تقع على السلطة المتعاقدة فى عقود البوت، هى الى كالتالى (ro) (ro) أ- التزامها بتوفير المناخ القانونى الملائم لاستقبال مشاريع عقود البوت: تلنزم السلطة المتعاقدة بالعمل على إنجاح مشاريع البوت، وذلك بتعزيز

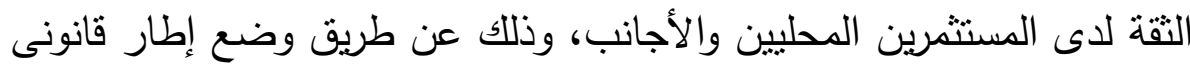


محكم يسمح بالاستثمار الخاص، ويكفل تحصيل عائداته، وذلك من خلال سن قوانين تسمح بملكية القطاع الخاص، وتمويل مرافق البنية التحتية وتتشغيلها،

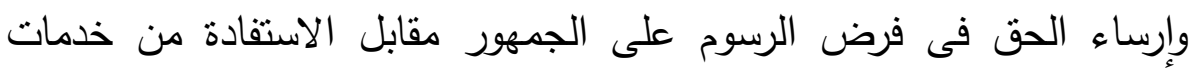

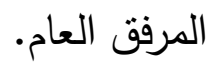

كما يتعيّن اتسام هذه التشريعات بالمرونة، والتى لا تعيق الآليات الاقتصادية لتمويل مشاريع البنية الأساسية، كما تضمن للمستثمر تحقيق أرباح مناسبة، وحماية رأس مال المشروع وأرباحه من المخاطر التجارية.

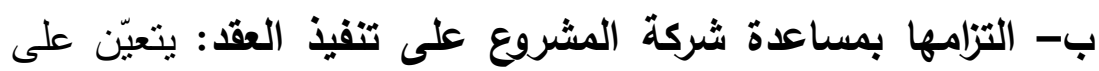

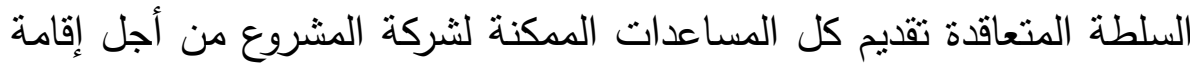
المشروع، ذلك من خلال منحها جميع التراخيص اللازمة أو تسهيل إجراءات

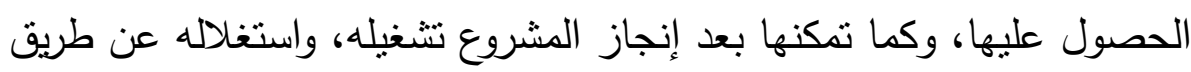

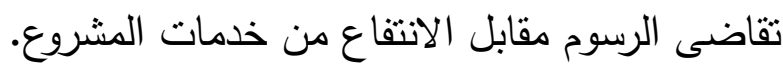

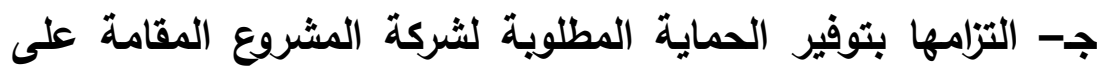

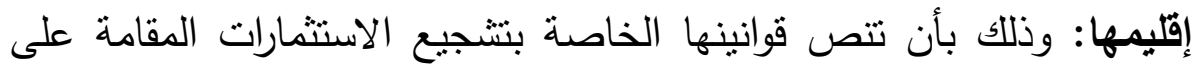

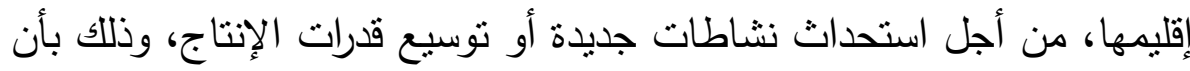

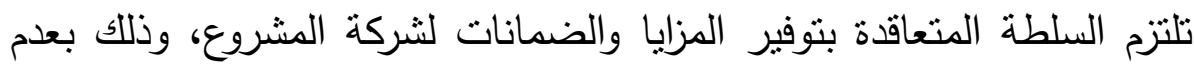

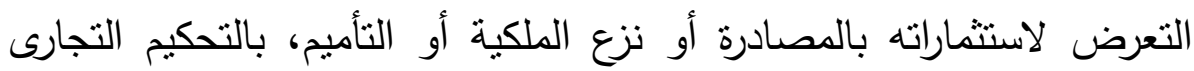

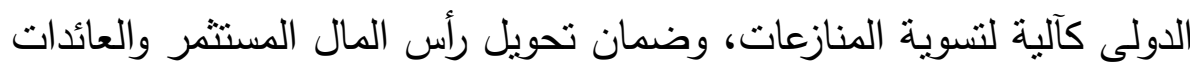
الناتجة عنه، وكل الدداخل إلى الخارج، وتحمل السلطة المتعاقدة لمخاطر القوة

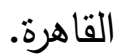




\section{r - r - عقوق السلطة المتعاقدة}

أ- حق السلطة المتعاقدة فى الرقابة على عقود البوت: منح السلطة المتعاقدة حق الرقابة على الاستثارات الأجنبية المنجزة على إقليمها، وحق توجيه هذه الاستثمارات بما يحقق أهداف التتمية المحلية والمصلحة العامة. على أن تمارس سلطة الرقابة فى إطار الحدود والضوابط المتقق عليها،

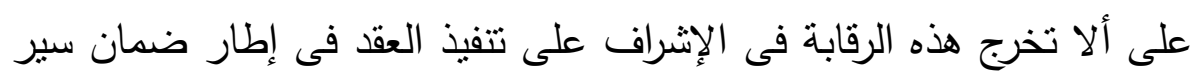

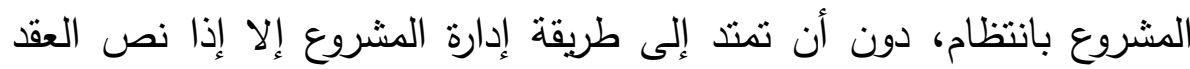

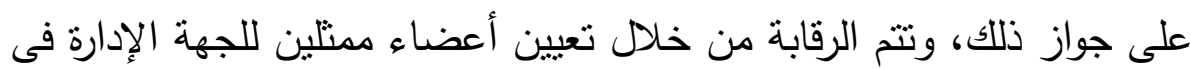
مجلس إدارة الشركة صاحبة المشروع، بالإضافة إلى حق تدخل الوزارات

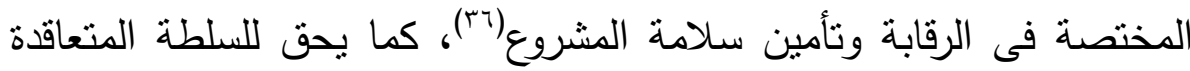

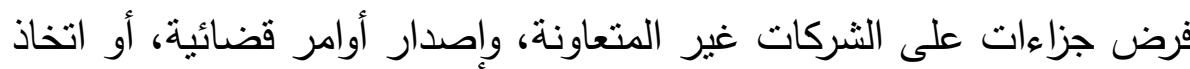
جزاءات جزائية لنفاذ تقديم المعلومات (؟V) ب- حقها فى تعديل عقد البوت بالإرادة المنفردة: يحق للسلطة المتعاقدة فى تعديل عقد البوت لما تطلبه مقتضيات المصلحة العامة، خاصة

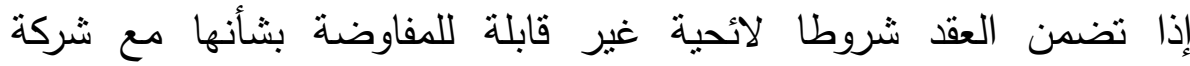

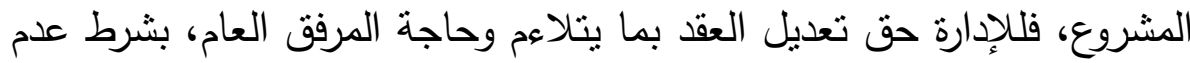
المساس بالضمانات المقررة لشركة المشروع، كما هو منصوص عليها فى عقد

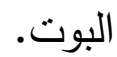

وقد نص المشروع الجزائرى في 14 من قانون المياه على أنه" يمكن فى

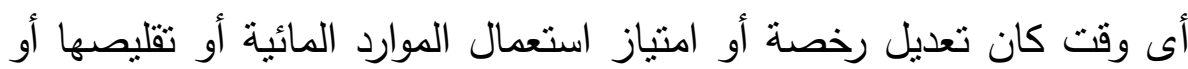

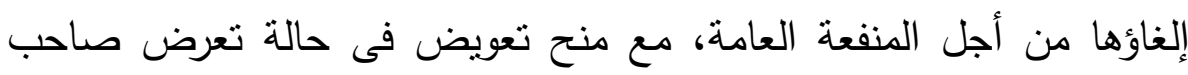

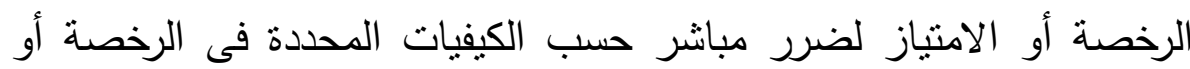




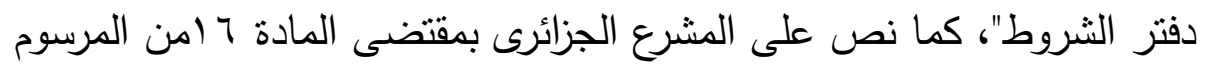

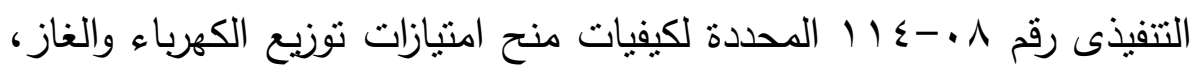

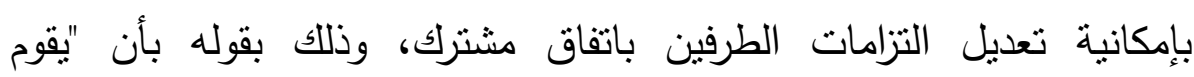

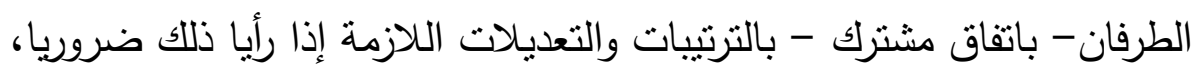
بعد استثارة لجنة الكهرباء والغاز".

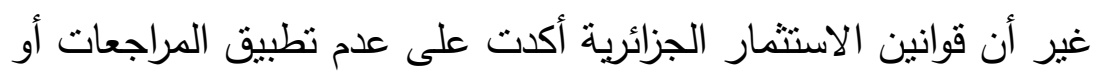

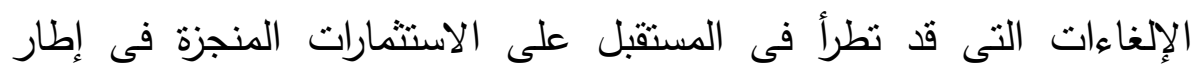

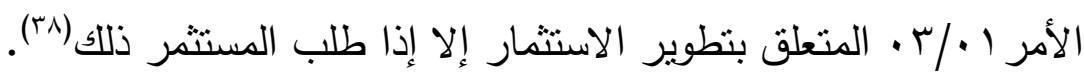

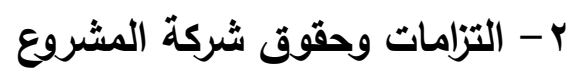

فى إطار هذا المطلب نتعرض إلى التزامات شركة المشروع فئرع فئ الفرع الأول، والحقوق المخوّلة لها للتنتع بها فى الفرع الثنانى.

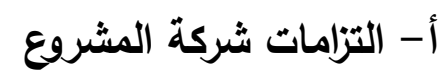

تنتوّع الالتزامات الواقعة على شركة المشروع فى عقود البوت، منها ما يتصل

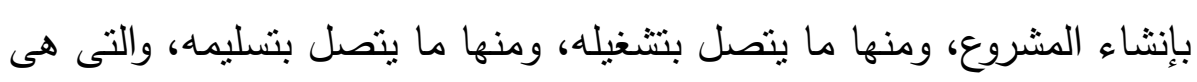

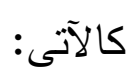

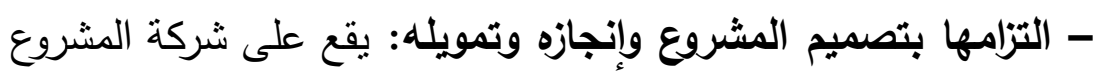

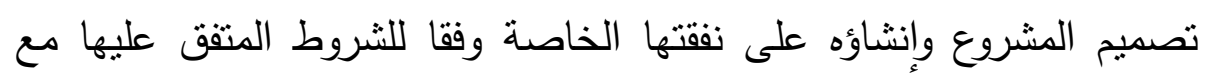
الإدارة المتعاقدة معها. - التزامها بإنجاز المشروع فى المواعيد المحددة له: تلتزم شركة

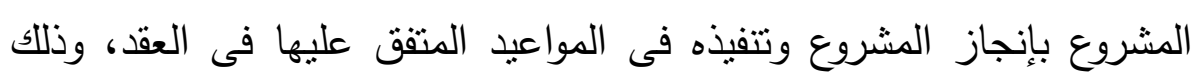
حتى يسمح للإدارة المنعاقدة معرفة أجل انتقال ملكية المشروع إليها، بعد انتهاء مدة الالتزام، فالتأخر فى التتفيذ بشكل خطأ عقديا يوجب التعويض، من خلال التهاء 
دفع غرامة التأخير للسلطة المنعاقدة، والتى يتم تحديدها فى عقد المبرم، ويرتبط

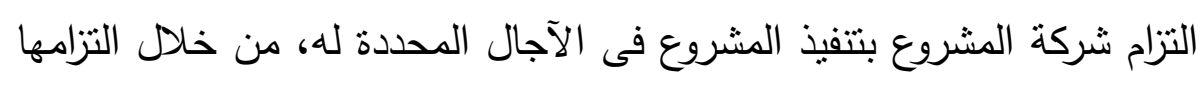

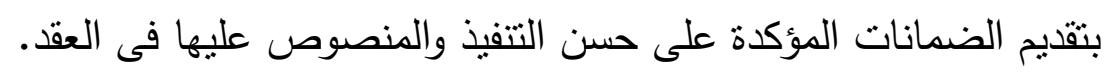

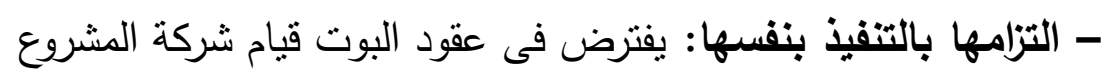

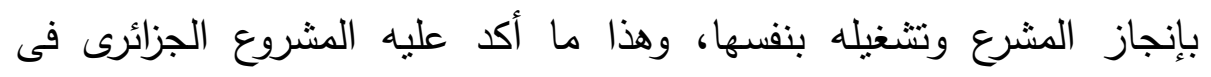

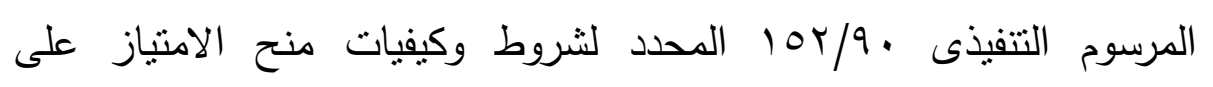

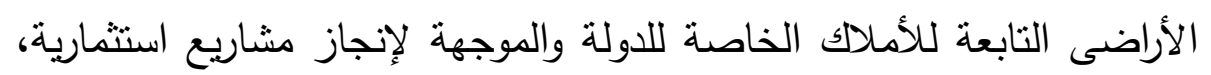
حيث نصت المادة r/lV على أنه" يجب أن يتضمن عقد الامتياز تحت طائلة البطلان، شروط منع التنازل أو الإيجار من الباطن للامثياز قبل إنمام

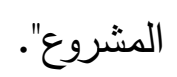

غير أن المشرع الجزائرى بمقتضى المادة •ـ من المرسوم التنفيذى رقم

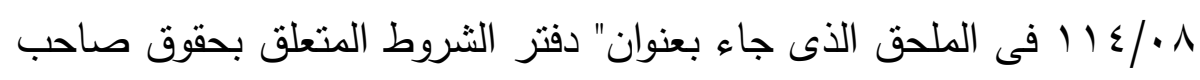

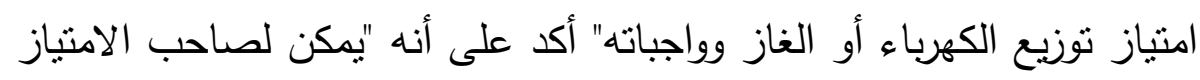

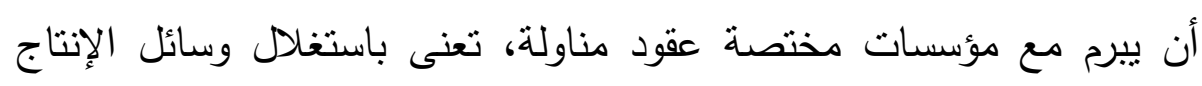

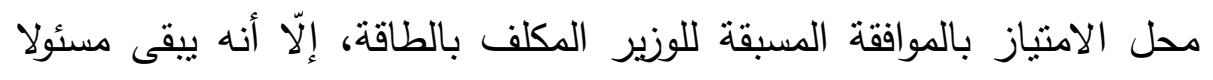

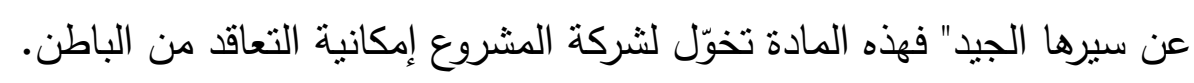

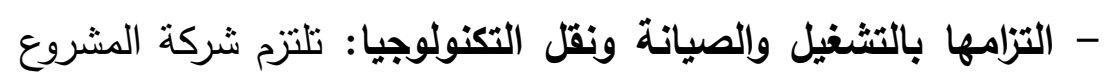

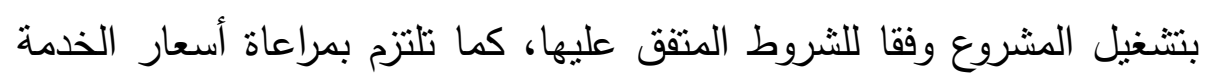

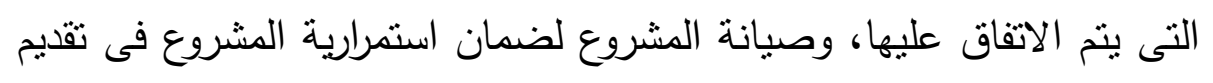

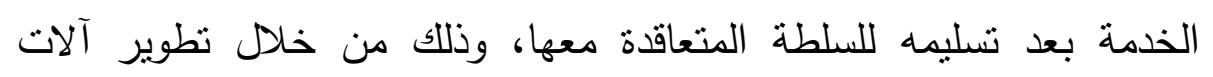

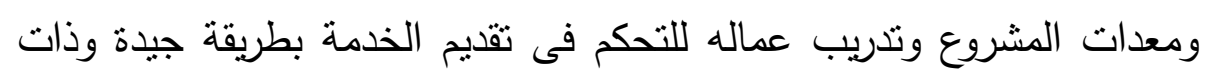
نوعية للزبائن. كما ينجيّن على شركة المشروع تزوّد الششروع بكل وسائل 
التكنولوجيا الحديثة، لضمان زيادة الإنتاج وقابلية المشروع فى إحداث التتمية

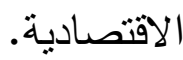
- التزامها بنقل ملكية المشروع فى نهاية مدة التعاقد: تلتزم شركة المشروع بعد انتهاء مدة التعاقد بنقل ملكية المرفق العام إلى الجهة الإدارية المتعاقدة معها بحالة جيدة، وذلك من دون مقابل، كما يتعيّن على شركة التهاه المشروع تسليم جميع المستندات والوثائق اللازمة لتشغيل المشروع، كما تلتزم بالتعاون مع الجهة الإدارية العائد إليها المشروع بالكيفية المتفق عليها.

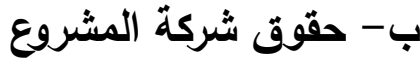
من الحقوق الممنوحة لثركة المشروع، نذكر الآتى:

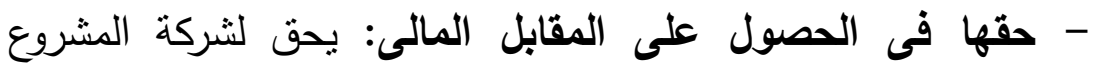

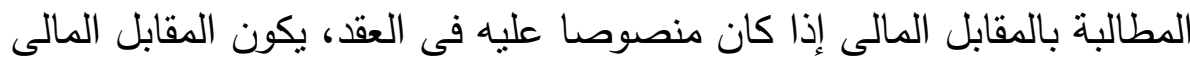

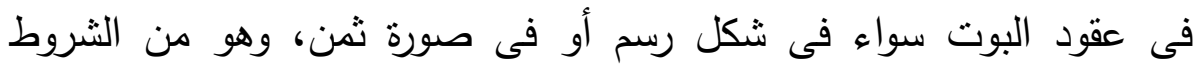
العقدية التى لا يجوز تعديلها إلا باتفاق الطرفين، وذلك من خلال مراعاة

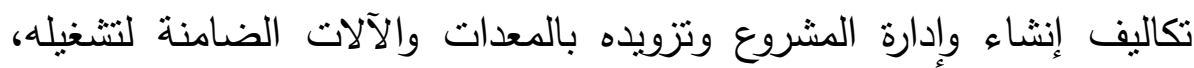
وطريقة دفع المقابل المالى وكيفية دفعه يكون منصوصا عليه فى العقد.

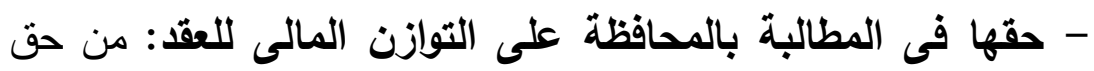

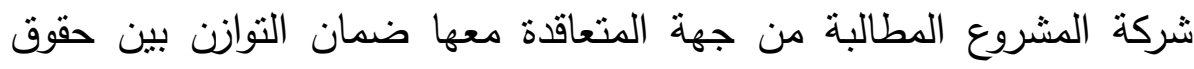

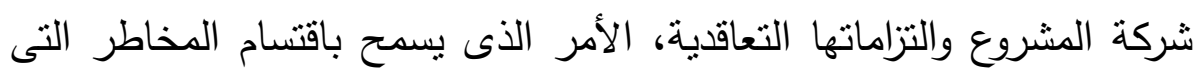

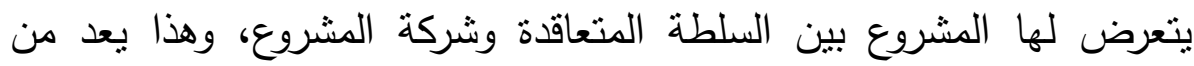

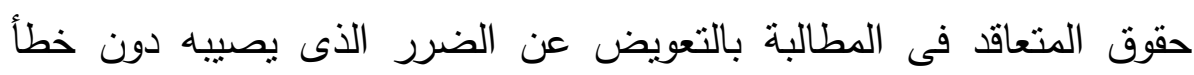
يرتكبه أو ينسب إليه. 
ويكون لثركة المشروع حق المطالبة بالتوازن المالى للعقد فى حالة

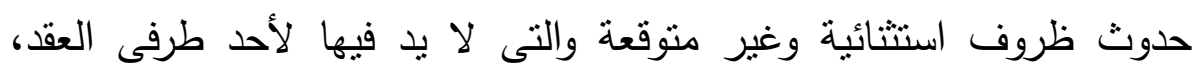
يجتمع المتعاقدان لمراجعة الالتزامات المتبادلة وتكييفها حسب المبات لمستجدات

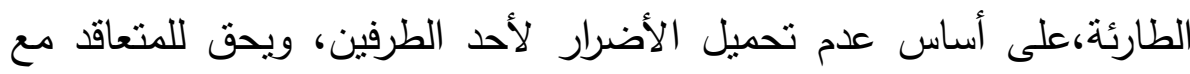

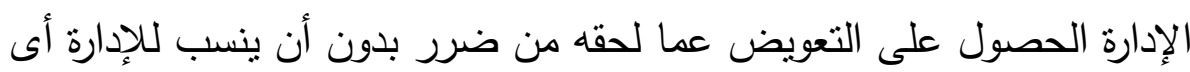

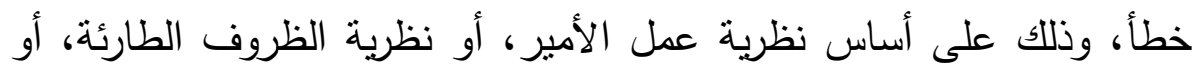
نظرية الصعوبات المالية غير المتوقعة( (؟9).

\section{الخاتمة}

تعد عقود البوت وسيلة مهمة فى رفع العبء الاقتصادى على الدول النامية باعتبارها إطارًا قانونيا يضمن تمويل مشروعات البنية الأساسية وإدارتها وفق التقال

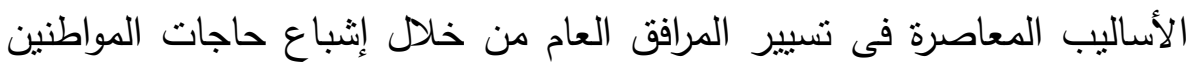

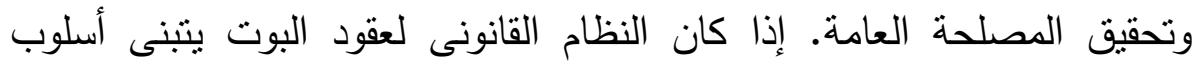

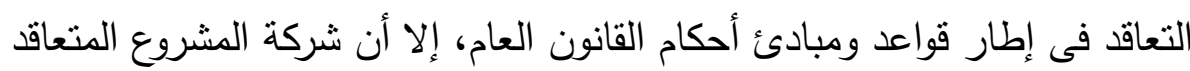

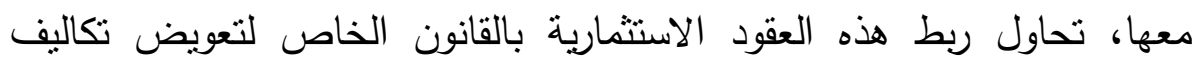
الاستثمار وتحقيق عائد مالى مناسب.

غير أن المشرع الجزائرى ألدق هذا النوع من التعاقد بمفهوم عقود الامتياز ،

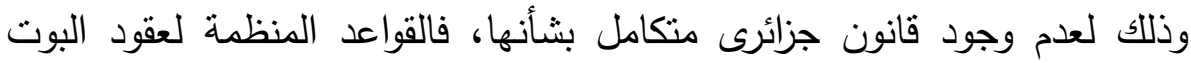
جاءت متقرقة وغير موحدة، وخاصة فى مجالات عقود المياه والكهباء والغاز والطرق والرى، وهى تخضع فى مجلها لقواعد القانون الإدارى.

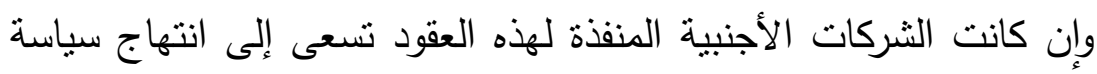

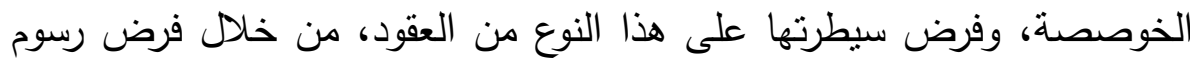
الخدمات ومحاولة احتكار الخدمة العامة. 
وللحد من خطورة الثركات الأجنبية المتعاقدة مع الدولة الجزائرية، عليها

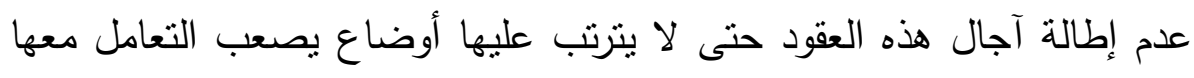

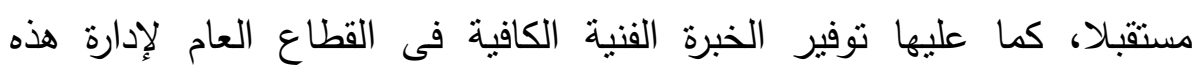

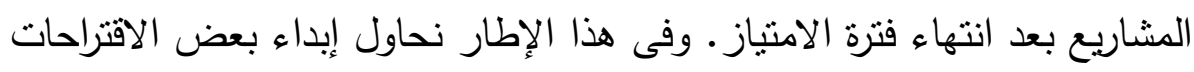

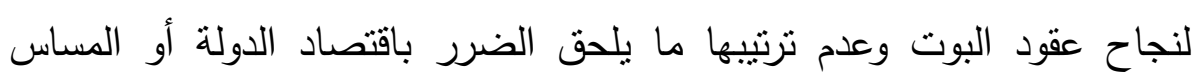
بسيادتها، من هذه الاقتراحات الآتى: أولا- وضع الضمانات الكافية لحماية أموال البنوك المقرضة لثركة الثرات المشروع عن طريق تقديم ما يضمن الوفاء بها من أصول الثركة.

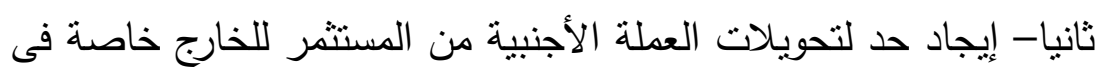
الحالات التى لا تتطلب شراء معدات وآلات من أجل المشروع.

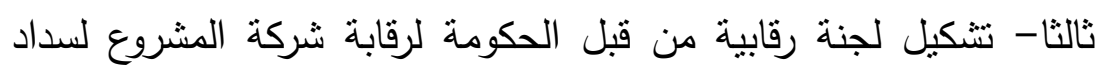

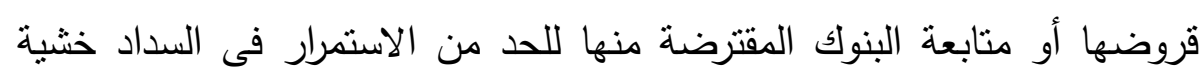
إفلاسها أو عدم قدرتها على أسداد.

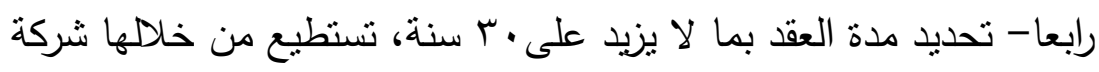

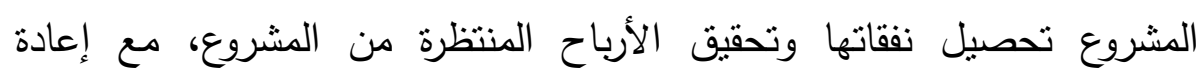

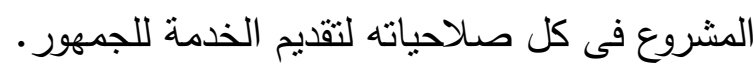

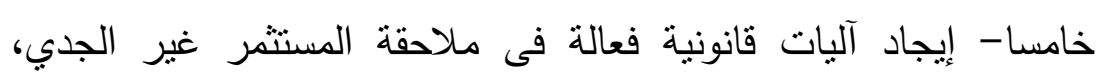

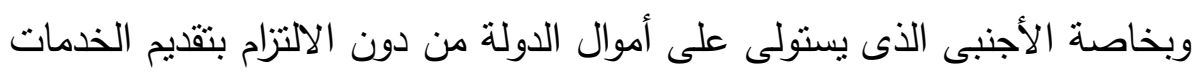
المنعاقد عليها، أو تقديمها بطريقة مخالفة لما تم الاتفاق عليه.

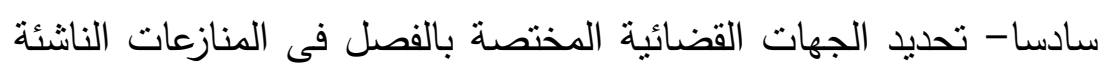
عن تلك العقود، يستوى أن يكون من جهات القضاء أو التحكيم على حد سواء. 


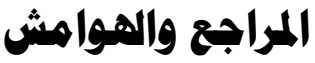

ا- إلياس ناصيف، سلسلة أبحاث قانونية مقارنة عقد البوت، المؤسسة الحديثة للكتاب،

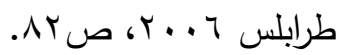

r- حامد ماهر محمد، النظام القانونى لعقود الإنشاء والتشغيل وإعادة المشروع، دار

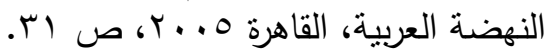

r- محمد الروبي، عقود التتييد والاستغلال والتنسليم البوت، دراسة فى إطار القانون

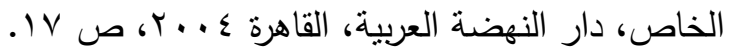

ع - عبد الفتاح بيومى حجازي، عقود البوت فى القانون المقارن، دار الكتب القانونية، المحلة

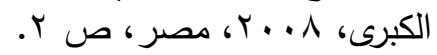

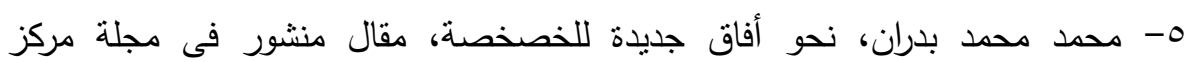

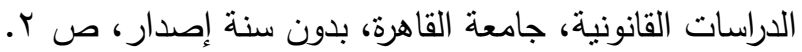

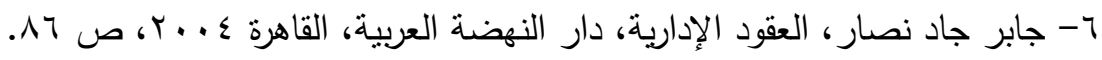
V- أحمد سلامة بدر ، العقود الإدارية وعقود البوت، دار النهضة العربية، القاهرة

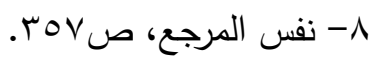

9- محمد أحمد غانم، مشروعات البنية الأساسية بنظام البوت، المكتب الجامعى الحديث،

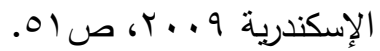

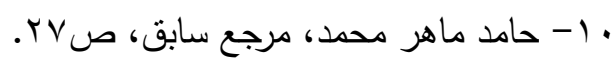

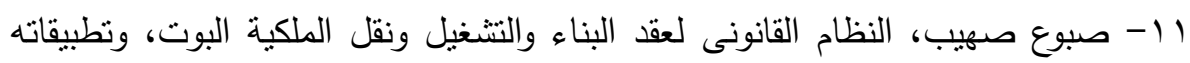

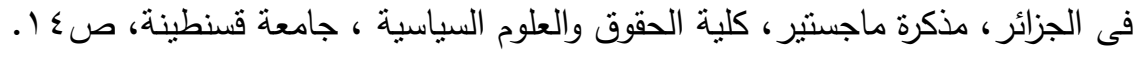
r إ- راجع تقرير لجنة الأمم المتحدة للقانون التجارى الدولى المتعلق بالأعمال المقبلة

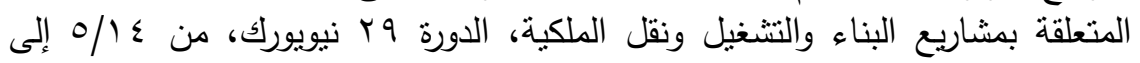
r

rا - وضاح محمود الحمود، عقود البناء والتشغيل ونقل الملكية( البوت)، عقود الإدارة

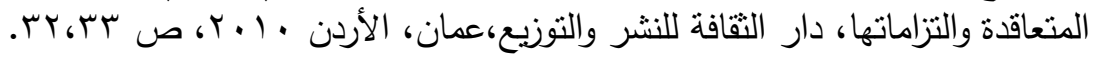

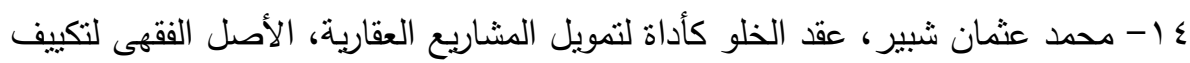

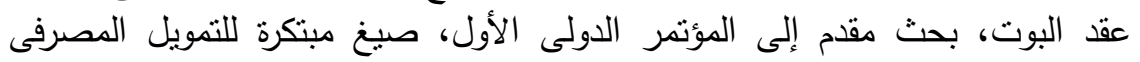


الإسلامي، المعهد العالى للدراسات الإسلامية ،جامعة آل البيت، المملكة العربية

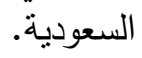

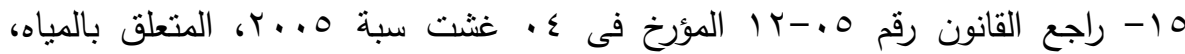

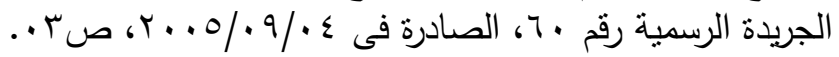

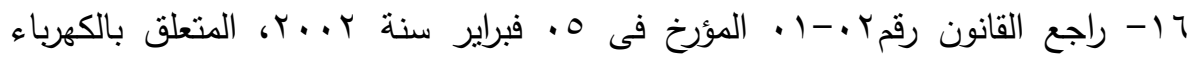

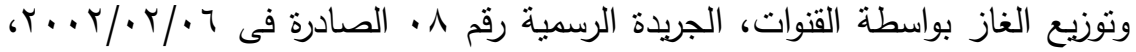
ص گ ؟.

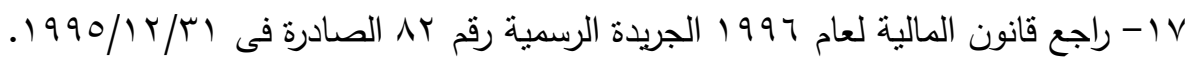

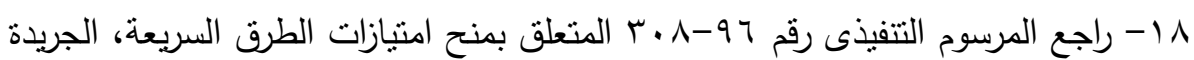

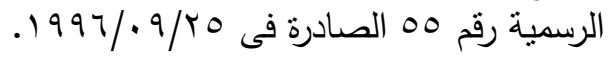

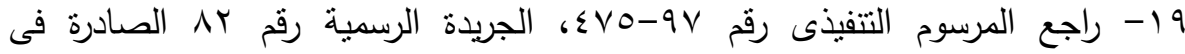
r.r. $999 / / Y / 1 \varepsilon$

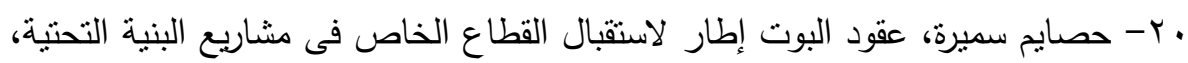

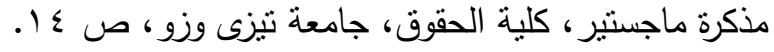

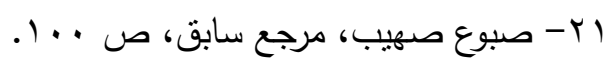

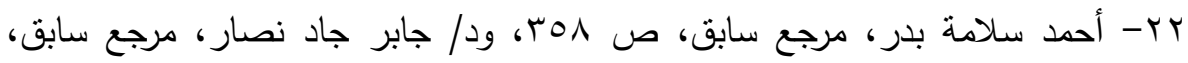

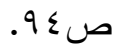

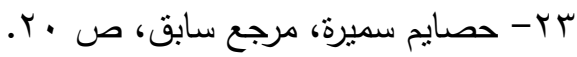

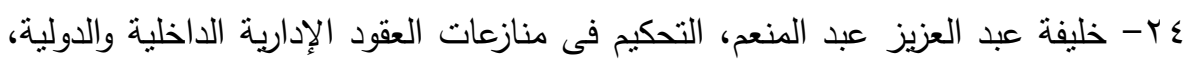

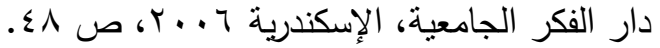

0r- صبوع صهيب، مرجع سابق، ص 01.

26- well.p.Droit International Public et Droit Administratif Mélanges Trotabas, p.52.

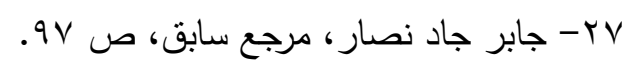

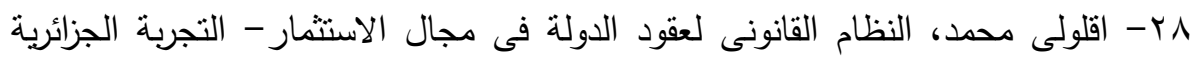

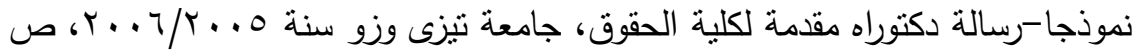

9ץ- عصام أحمد البهجي، عقود البوت الطريق لبناء مرافق الدولة الحديثة، دار الجامعة

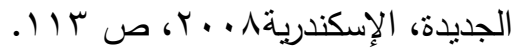




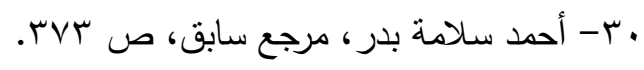

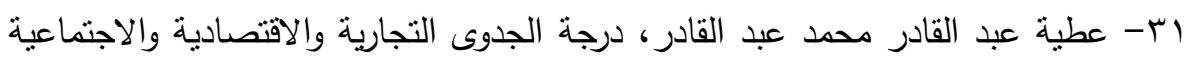

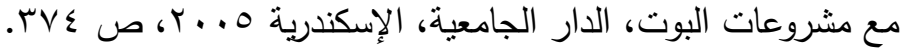

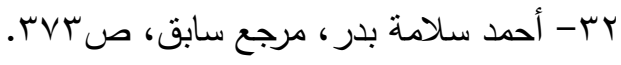

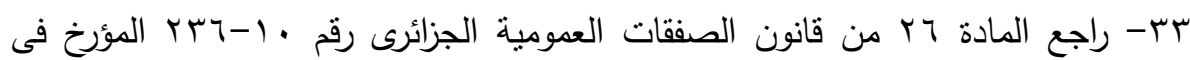

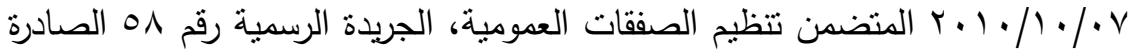

$$
\text { فى }
$$

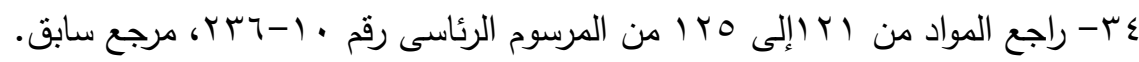

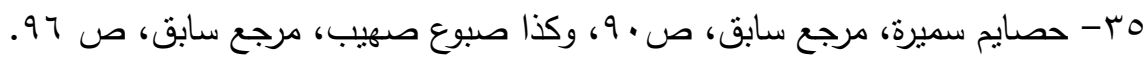

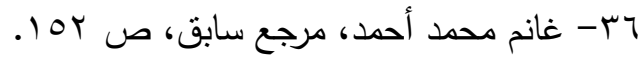

- TV

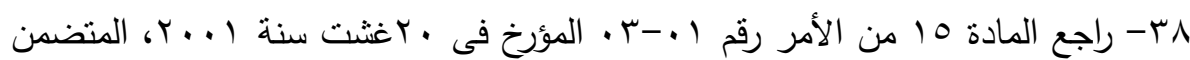

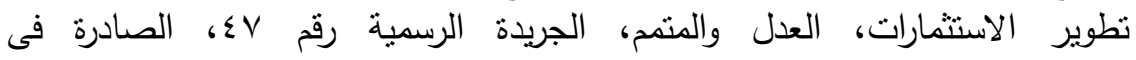
. r.. 1/. 1/ r r

q؟- جابر جاد نصار ، عقود البوت -التطور الحديث لعقد الالتزام، دار النهضة العربية،

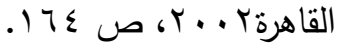




\section{La Nature des Marchés et Leurs Effets Juridiques}

\section{Ibrahim Mogahedi}

Les contrats de Bot sont des systèmes juridiques innovants par rapport aux contrats de concession et ont été utilisés dans des projets d'infrastructure qui sont soumis à des réglementations légales. Ces contrats ont été instaurés après le déficit budgétaire de certains pays, ce qui a conduit ces derniers à l'application de nouveaux mécanismes pour stimuler le secteur privé en projets d'infrastructure, comme les routes, le transport, l'hydraulique, l'électricité et le gaz, la production de toute sorte d'énergie, le transport ferroviaire et routier, ainsi que dans certains créneaux du commerce international.

L'investissement dans l'infrastructure en impliquant le secteur privé crée un développement interne sans nuire à l'intérêt public des pays qui engagent ce genre de contrats. 
